\title{
Northwestern University, The University of Missouri, and the "Student-Athlete": Mobilization Efforts and the Future
}

\author{
Adam Epstein and Kathryn Kisska-Schulze
}

\begin{abstract}
Student-athletes have a powerful voice in issues that matter to them. This was most recently demonstrated in two ways, including the 2014 Northwestern University football team's unsuccessful attempt to organize as a union, and the 2015 University of Missouri's successful demonstration, both in-person and via social media, ultimately resulting in the resignation of the president of the University. The paper explores the history of student-athlete mobilizations and demonstrates that it should come as no surprise to see increasingly public attempts in the future as student-athletes become more aware of their rights and the campaigns and concerns of others. Student-athletes may continue to influence public opinion and NCAA member institutions as the NCAA rules evolve in the era of social media and instant access to causes and campaigns.
\end{abstract}

On November 7, 2015, a University of Missouri (UM or Missouri) football player initiated a modern-day student-athlete mobilization by tweeting,

The athletes of color on the University of Missouri football team truly believe "Injustice Anywhere is a threat to Justice Everywhere" We will no longer participate in any football related activities until president Tim Wolfe resigns or is removed due to his negligence toward marginalized students' experiences. WE ARE UNITED!!!!!!.

Within 24 hours, more than 30 members of the UM football team had joined the protest, boycotting practices and games during the middle of the college football season, until Wolfe resigned or was terminated. ${ }^{2}$

\footnotetext{
${ }^{1}$ Scott Gleeson, USA Today, Missouri Football Players to Boycott until President Tim Wolfe Resigns (Nov. 8, 2015, 11:26AM), http://www.usatoday.com/story/sports/ncaaf/2015/11/07/missouri-tigersfootball-players-boycott-tim-wolfe-president-resigns/75399504/ (offering the tweet posted by sophomore defensive back Anthony Sherrils, @ 1Sherrils_2MIZZ). For the purposes of our article, the word "mobilization" will be used loosely and interchangeably with activism, to mean that one or more student-athletes came together through collective action for a purpose so that their voices would be heard as a means to effect change. In essence, one or more student-athletes rallied for a particular cause. ${ }^{2} I d$.

Epstein (JD, M.B.A.) is with the Dept. of Finance and Law, Central Michigan University. KisskaSchulze (JD, LL.M.) is with the College of Business, Clemson University. Epstein (adamepstein@ outlook.com) is corresponding author.
} 
The team's high-profile unification drew national attention instantly, and helped bridge the gap between student-athlete and the Columbia community by forcing the University to address campus concerns related to race, an issue that the state was already quite familiar with. ${ }^{3}$ The success of the student-athlete boycott, epitomized by Wolfe's resignation a few days later, demonstrated the impact that student-athletes can have on college campuses. ${ }^{4}$

The Missouri football team's 2015 activist effort was not the first of its kind in college sports, but marked one of the most effective and passionate mobilization campaigns in recent college sports history. ${ }^{5}$ For decades, evidence of student-athlete unification and activism has spanned multiple genres, including inequities related to civil rights, workers' compensation claims, unionization attempts, unsuitable facilities, and other demands to address perceived economic injustice.

Although not all mobilization efforts have proven to be as successful as the Missouri boycott, it is evident that student-athletes have a powerful voice in promoting national debate as evidenced by the 2014 Northwestern University (NU or Northwestern) football team's unsuccessful-yet valiant-attempt to organize as a union. ${ }^{6}$ The National Labor Relations Board (NLRB) ultimately rejected the attempt by NU football players to unionize and bargain collectively, but the attempt to organize reignited the discussion as to whether or not student-athletes (in this

\footnotetext{
${ }^{3}$ See Chuck Culpepper, How Missouri Football's Boycott Helped Bridge a Familiar Campus Divide, WAsh. Post (Nov. 13, 2015), https://www.washingtonpost.com/sports/colleges/ how-missouri-footballs-boycott-helped-unite-a-troubled-campus/2015/11/13/64fe68ea-8a0f11e5-be8b-1ae2e4f50f76_story.html.

${ }^{4}$ Jake New, The Power of a Football Boycott, Inside Higher Ed (Nov. 11, 2015), https:// www.insidehighered.com/news/2015/11/11/u-missouri-football-boycott-demonstrateseconomic-power-athletes (providing that the University of Missouri would have owed Brigham Young University (BYU) \$1 million for the game had Missouri been unable to field a team against BYU, the weekend following the football team's boycott initiative).

${ }^{5}$ See generally Ronald A. SMITh, PAy For Play (2011) (offering a history of the formation and evolution of the NCAA itself as a result of "brutal nature of football, with few deaths and many severe injuries." Smith goes on to discuss the role that college presidents have played over the years to shape the NCAA whether for safety concerns in football, academic reform, the role of amateurism, freshman ineligibility, and enforcement of penalties against violators such as the "death penalty" received by Southern Methodist University football team for egregious misconduct in the 1980s); see also Joe Nocera \& Ben Strauss, Indentured 14 (2016) (discussing the influence of football as the marquee sport in college athletics and stating "By the 1940s, football was by far the most popular college sport..."). Based upon our research, the vast majority of examples of student-athlete mobilization over the decades has emanated from those who participate in football. This could be due to the marquee nature and prominence of the sport on college campuses and as a rallying point for the community and alumni for over 100 years. After all, football not only has always been the driving force behind intercollegiate sport and the NCAA, but it was the primary reason for the development of the organization in the first place and has been the primary motivation for antitrust litigation and conference realignments. However, activism and outspoken opinion and reform is not limited to football alone as this article demonstrates.
}

${ }^{6}$ See Northwestern Univ. \& College Athletes Players Ass'n (CAPA), 362 N.L.R.B. No. 167 (Aug. 17, 2015). 
case college football players) should be characterized as employees in the first place, and therefore compensated financially to play college sports. ${ }^{7}$

The purpose of this paper is to explore the history of student-athlete mobilizations and demonstrate that it should come as no surprise to see increasingly public attempts in the future as student-athletes become more aware of their rights and the campaigns of others. Part I of this article examines the relationship between the student-athlete and their representative institution from an historical perspective, and includes a discussion of select workers' compensation cases and race-related demonstrations that helped define this evolving relationship between the student-athlete and the institution. Part II summarizes the NU-NLRB case, in which football players at NU attempted to form a union, and explores the effective mobilization efforts at Missouri the following year which led to the resignation of university president Tim Wolfe. ${ }^{8}$ Part III explores the NCAA's response to the Northwestern and Missouri mobilization efforts, and assesses the impact that student-athletes may continue to have on NCAA member institutions as the NCAA rules evolve and lawsuits work their way through the judicial system in the era of social media and instant access to information.

\section{The Evolving Relationship Between "Student- Athletes" and Their Representative Institutions}

\section{The "Student-Athlete" as Amateur}

For decades, the NCAA has adamantly maintained that student-athletes are unpaid amateurs. ${ }^{9}$ In fact, much has been written about the invention of the expression "student-athlete" by the NCAA and whether or not it is a mischaracterization. This expression has come under scrutiny for years, and many have questioned whether or not more accurate portrayals of the true characterization of college athletes are just as students, ${ }^{10}$ student-employees, ${ }^{11}$

\footnotetext{
${ }^{7}$ See Kathryn Kisska-Schulze \& Adam Epstein, The National Labor Relations Board v. Northwestern University: Cultivating a New Era for Taxing Qualified Scholarships, forthcoming, Akron L. Rev. (2016); see also Northwestern Univ. \& College Athletes Players Ass'n (CAPA), 362 N.L.R.B. No. 167 (Aug. 17, 2015).

${ }^{8}$ See, e.g., Amandha Rohr Lopes, The Impact of Social Media on Social Movements: The New Opportunity and Mobilizing Structure, J. Political Science Research, at 2 (2014), https://www.creighton.edu/fileadmin/user/CCAS/departments/PoliticalScience/Journal_of_ Political_Research_JPR_/2014_JSP_papers/Lopes_JPR.pdf.

${ }^{9}$ See Kathryn Kisska-Schulze \& Adam Epstein, "Show Me the Money!" - Analyzing the Potential State Tax Implications of Paying Student-Athletes, 14 VA. Sports \& ENT. L.J. 13, 21-22 (2014).

${ }^{10}$ See, e.g., Bernie Lincicome, Pretense of Student-athletes Just Part of the College Game, CHI. TriB. (Aug. 23, 2015), http://www.chicagotribune.com/sports/columnists/ct-college-sports-sham-lincicomespt-0823-20150822-column.html.

${ }^{11} \mathrm{Id}$.
} 
athlete-students, ${ }^{12}$ or even special admits. ${ }^{13}$ Undoubtedly, the relationship between student-athletes and the NCAA's member institutions has been a peculiar one given that student-athletes are the only members of the student population that cannot be paid in cash for services rendered because such payment would violate the NCAA's fundamental principle of amateurism. ${ }^{14}$

Despite this NCAA's noble amateurism ideal, ${ }^{15}$ a position relinquished by the Olympic Movement decades ago, ${ }^{16}$ student-athletes have been paid for their services, albeit in violation of NCAA rules, for years. ${ }^{17}$ In some instances, defiance of the NCAA amateurism rules (known as bylaws) have resulted in the complete suspension of a college athletic program for a one-year term, as happened in the infamous Southern Methodist University quandary of the 1980s. ${ }^{18}$ Noted author Taylor Branch documented in a much earlier incident in 1939 that "freshmen players at the University of Pittsburgh went on strike because they were getting paid less than their upperclassmen teammates."19

\begin{abstract}
${ }^{12}$ Daniel Oppenheimer, Why Student Athletes Continue to Fail, Time.com (Apr. 20, 2015), http:// time.com/3827196/why-student-athletes-fail/; see also Sarah E. Gohl, Note: A Lesson in English and Gender: Title IX and the Male Student-athlete, 50 Duke L.J. 1123, 1123-24 (2001); Michael Rosenberg, Michigan Coach Jim Harbaugh Rips Recent Satellite Camp Vote: 'I Suggest We Drop the Term Student-Athlete,"' CAmpusRush.com (Apr. 12, 2016), http://www.campusrush.com/ jim-harbaugh-satellite-camp-ban-student-athlete-comments-1725253351.html?xid=si_social (writing that the head football coach was unhappy with the decision to drop off-campus satellite camps and quoting Harbaugh, "During the NCAA basketball tournament we discuss the term 'student-athlete' ad nauseam in promoting our governing institution and our member institutions. Then, when we have an opportunity to truly promote the 'student-athlete' with a concept shared by educators and football men from all backgrounds, our leadership goes into hiding.").
\end{abstract}

${ }^{13}$ M. Tae Phillips, Note: Un-Equal Protection: Preferential Admissions Treatment for Student Athletes, 60 Ala. L. REv. 751, 758 (2009). Based upon our research via a Lexis.com search for "student athlete" in the Federal and State cases combined database, the first time a published decision utilized the expression was in State Comp. Ins. Fund v. Indus. Accident Comm'n, 314 P.2d 288, 290 (Colo. 1957) ("We cannot believe that the legislature, in creating the compensation fund, intended that it be in the nature of a pension fund for all student athletes attending our state educational institutions."), discussed further, infra.

${ }^{14}$ See Taylor Branch, The Shame of College Sports, AtLantic (Oct. 2011), http://www.theatlantic. com/magazine/archive/2011/10/the-shame-of-college-sports/308643/.

${ }^{15} \mathrm{Id}$.

${ }^{16} I d$. (offering that "The International Olympic Committee expunged the word amateur from its charter in 1986." Taylor then adds, "Olympic officials, who had once disdained the NCAA for offering scholarships in exchange for athletic performance, came to welcome millionaire athletes from every quarter, while the NCAA still refused to let the pro Olympian Michael Phelps swim for his college team at Michigan.”).

${ }^{17} \mathrm{Id}$.

${ }^{18} I d$. (noting that the NCAA's "death penalty" sentences (season-long shutdowns of teams in violation of NCAA bylaws) included Kentucky (1952), Southwestern Louisiana (1973), and Southern Methodist University (1987)).

${ }^{19}$ Id.; see also SмIтH, supra note 5, at 79 (noting that in 1938, there was a strike by Pittsburgh sophomore football players who were required to work more than the upperclassmen if they wanted their tuition to be paid. This, of course, reflected an entirely different era and the expectation of the student-athlete for their scholarship.). 
Although the NCAA stands behind its position that there is a clear line of demarcation ${ }^{20}$ between professional athletes and the student-athlete who must remain an amateur, ${ }^{21}$ the issue of whether student-athletes should be paid, and thus morph the student-athlete characterization from one of amateur to that of professional athlete, rose to a national debate during the 2013-2014 college football season. ${ }^{22}$ In September 2013, then-Texas A\&M University sophomore and Heisman Trophy winner Johnny Manziel was featured on the cover of Time Magazine with the headline, "It's Time to Pay College Athletes." 23 Throughout that season, Manziel made "Show Me the Money" hand gestures following big plays, prompting a nation-wide discussion of the pay-for-play model with respect to college athletics. ${ }^{24}$

While the NCAA continues to stand firm on its stance that student-athletes are in fact amateurs and cannot be paid to play college sports, a 2014 decision rendered by federal judge Claudia Wilken appeared to open to the door to allow studentathletes to receive up to $\$ 5,000$ per year to compensate students for the potential use of their likeness (although the $\$ 5,000$ part of the decision was later overturned in 2015). ${ }^{25}$ In fact, in October 2014 the University of Texas' Athletic Director at the time of Wilken's decision, Steve Patterson, announced the University's intent to pay each of its student-athletes $\$ 10,000$ a year to cover the cost of attendance (COA) and likeness rights beginning fall 2015. ${ }^{26}$

20 See National Collegiate Athletic Ass'n, 2015-2016 NCAA DivisION I MANUAL, art. 1.3.1
(effective Oct. 1, 2015) (hereinafter "NCAA MANUAL") ("A basic purpose of this Association is
to maintain intercollegiate athletics as an integral part of the educational program and the athlete
as an integral part of the student body and, by so doing, retain a clear line of demarcation between
intercollegiate athletics and professional sports.") ${ }^{21}$ Id. art. 2.9; see also Adam Epstein \& Paul Anderson, Utilization of the NCAA Manual as a Teaching Tool, 26 J. Legal Stud. Educ. 109 (2009).

${ }^{22}$ See Darren Heitner, Should College Athletes Be Paid, Sports Marketing Media (Oct. 1, 2013), http://www.sportsagentblog.com/2013/10/01/should-college-athletes-be-paid/.

${ }^{23}$ See Kisska-Schulze \& Epstein, supra note 9.

${ }^{24}$ Id.; see also Dan Carson, Texas A\&M President Flashes Johnny Manziel's 'Show Me the Money' Gesture, BlEACHER RePORT (Sept. 6, 2013), http://bleacherreport.com/ articles/1763834-texas-am-president-throws-up-johnny-manziels-show-me-the-money-gesture.

${ }^{25}$ O'Bannon v. NCAA, 7 F. Supp. 3d 955, 962-63 (N.D. Cal. 2014), aff'd in part and rev'd in part by O'Bannon v. NCAA, 802 F.3d 1049, 2015 U.S. App. LEXIS 17193 (9th Cir. Cal., 2015); see also ESPN.com News Services, Judge Rules Against NCAA, ESPN.com (Aug. 9, 2014, 6:20 PM), http://espn. go.com/college-sports/story/_id/11328442/judge-rules-ncaa-ed-obannon-antitrust-case (offering that U.S. District Judge Claudia Wilken, in a 99-page decision finding in favor of plaintiffs, found that "the NCAA rules unreasonably restrain trade in the market for certain educational and athletic opportunities offered by NCAA Division I schools." However, the article notes that she did rule that individual schools can offer less money so long as they do not unlawfully conspire among themselves to set those amounts.).

${ }^{26}$ See Zach Barnett, Texas Will Begin Paying Each of Its Athletes \$10,000 A Year, FootBall Scoop (Oct. 22, 2014), http://footballscoop.com/news/texas-will-begin-paying-athletes-10000-year/; see also Jason McIntyre, Texas is NOT Paying Each Athlete \$10,000, But AD Steve Patterson Said They Might if UT Loses in Court, BIG LEAD (Oct. 22, 2014, 11:46 PM ET), http://thebiglead.com/2014/10/22/ texas-is-not-paying-each-athlete-10000-but-ad-steve-patterson-said-they-might-if-ut-loses-in-court/ (disputing the original claim that Texas will pay each student-athlete $\$ 10,000$, but noting that such payment will occur if the University of Texas loses in court). 
While these relatively minimal COA payments are now acceptable under NCAA rules, ${ }^{27}$ it was only through the hard-fought efforts of plaintiff Ed O'Bannon, a former student-athlete at University of California, Los Angeles (UCLA), to secure such significant achievement in the relationship between the NCAA and its unpaid labor force: student-athletes. As this article demonstrates, it is clear that the current legal landscape is not on the side of student-athletes who claim that their status should be that of an employee, but rather falls directly in line with the NCAA's current stance on amateurism.

\section{“Student-Athlete" and Workers' Compensation Claims}

It is well-documented that the term "student-athlete" was created by the NCAA to avoid consideration in the American lexicon that college students who were on athletic grants-in-aid might ever be characterized as employees. ${ }^{28}$ This nomenclature was devised in direct response to cases which could have changed the relationship between the NCAA, its member schools, and its array of scholarship football players. ${ }^{29}$ Though workers' compensation cases by themselves do not constitute student-athlete mobilizations per se, these cases which started in the 1950s demonstrated that student-athletes were willing to challenge the system at that time which did not characterize them as employees. More specifically, these student-athletes, now plaintiffs, felt that their relationship with their institutions could be characterized as employer-employee and therefore they should be compensated like other workers who were injured in the course of their employment. Thus, though the claims were specific to individuals, and almost always were unsuccessful, the challenges in court marked the beginnings of the willingness to assume an adverse relationship with their institutions in the American legal system, if they could not be resolved otherwise.

\footnotetext{
27 See Marc Tracy \& Ben Strauss, Court Strikes Down Payments to College Athletes, N.Y. Times (Sept. 30, 2015), http://www.nytimes.com/2015/10/01/sports/obannon-ncaa-case-court-ofappeals-ruling.html?_r=0 (noting that in the Ninth Circuit Court of Appeals' “...panel's words, wrote that the NCAA was "not above the antitrust laws" and that its rules had been too restrictive in maintaining amateurism. But the appeals panel threw out the judge's proposal that the N.C.A.A. allow colleges to pay athletes up to $\$ 5,000$ per year in deferred compensation.").

${ }^{28}$ See Branch, supra note 14. As Branch explains it, "the term student-athlete was deliberately ambiguous. College players were not students at play (which might understate their athletic obligations), nor were they just athletes in college (which might imply they were professionals). That they were high-performance athletes meant they could be forgiven for not meeting the academic standards or their peers; that they were students meant that they did not have to be compensated, ever, for anything more than the cost of their studies. Student-athlete became the NCAA's signature term, repeated constantly in and out of courtrooms."
}

${ }^{29} \mathrm{Id}$. 
The University of Denver (also known as DU or Colorado Seminary), presented one of the first opportunities for a court to hear a case involving an injured scholarship athlete who then filed a workers' compensation claim. ${ }^{30}$ In the 1953 decision Univ. of Denver v. Nemeth, DU football player Ernest Nemeth not only played for the college, but also worked there, receiving fifty dollars per month, as well as meal deductions and housing accommodations, in exchange for cleaning sidewalks, caring for the campus tennis court, and maintaining the campus furnace ${ }^{31}$ However, these jobs were contingent upon his participation on the school football team. ${ }^{32}$ Specifically, if Nemeth failed to produce on the football field, his compensation at DU would have ended. ${ }^{33}$ This arrangement would violate NCAA bylaws today as such quid pro quo relationship would be considered an extra benefit. ${ }^{34}$

Nemeth sustained various injuries while engaged in spring football practice. ${ }^{35}$ He brought a claim for workers' compensation, alleging that he was employed by the University to play football and that the injury arose out of and in the course of employment. ${ }^{36}$ DU defended that it was engaged solely in the field of education, that the injury did not arise out of or in the course of Nemeth's employment, and that a financial award would contravene public policy. ${ }^{37}$ The Supreme Court of Colorado ruled that the mere fact that a student may "augment the funds necessary for [his] maintenance while attending the University" did not alter the fact that he may be an employee for workers' compensation purposes. ${ }^{38}$

${ }^{30}$ Univ. of Denver v. Nemeth, 257 P.2d 423 (Colo. 1953); see also Univ. of Denver v. Indus. Comm'n of Colorado, 335 P.2d 292, 294 (Colo. 1959) (holding that even though Nemeth accepted a lump sum payment for his $15 \%$ permanent disability, when he subsequently asked for more compensation due to a change in his condition, the Supreme Court of Colorado declared that private agreements may neither violate public policy nor abrogate statutory requirements such as through private agreements under the workers' compensation system established at that time, and the decision to reopen Nemeth's case was affirmed).

${ }^{31}$ Univ. of Denver v. Nemeth at 424.

${ }^{32} I d$. at 394-95.

${ }^{33}$ Univ. of Denver, 257 P.2d at 425-26. The court also noted "Higher education this day is a business, and a big one ... . A student employed by the University to discharge certain duties, not a part of his education program, is no different than the employee who is taking no course of instruction so far as the Workmen's Compensation Act is concerned." Id. at 426.

${ }^{34}$ See NCAA ManUAL, art. 16.02.3 (Extra Benefit), "An extra benefit is any special arrangement by an institutional employee or representative of the institution's athletics interests to provide a student-athlete or the student-athlete family member or friend a benefit not expressly authorized by NCAA legislation. Receipt of a benefit by student-athletes or their family members or friends is not a violation of NCAA legislation if it is demonstrated that the same benefit is generally available to the institution's students or their family members or friends or to a particular segment of the student body (e.g., international students, minority students) determined on a basis unrelated to athletics ability.").

35 Univ. of Denver v. Nemeth at 424.

${ }^{36} \mathrm{Id}$. at 425 .

${ }^{37} \mathrm{Id}$.

${ }^{38} \mathrm{Id}$. 
Therefore, the Court allowed Nemeth to recover for his injuries under workers' compensation, a decision that had an immediate and significant impact on the perception of student-athletes and their relationship to their schools. ${ }^{39}$

In 1957 the Supreme Court of Colorado again addressed the issue of whether a scholarship football player could be entitled to workers' compensation in State Compensation Insurance Fund v. Industrial Accident Commission. ${ }^{40}$ The Court was presented with a factual scenario similar to that in Nemeth, except in this case the student-athlete, Ray Dennison, died two days after suffering a head injury on the opening play of a football game. ${ }^{41}$ In denying recovery to Dennison's widow, the Court reasoned that the "college did not receive a direct benefit from the activities, since the college was not in the football business and received no benefit from this field of recreation." ${ }^{2}$ The Court then decided that because there was no contract between Dennison and the college for his football participation, the injury was not an incident of or caused by his employment by the college. ${ }^{43}$ The Court ruled that the college was "not in the football business" and Dennison's claim was ultimately unsuccessful. ${ }^{44}$

The Court emphasized that without a contractual obligation to play football between student-athlete and University, there is no employer-employee relationship to which workers' compensation is applicable. ${ }^{45}$ Rather than overturning Nemeth, the Court distinguished Dennison's case from Nemeth by finding that Nemeth's employment "depended wholly on his playing football and it is clear that if he failed to perform as a football player he would lose the job provided for him by the University." 46

${ }^{39}$ Id. at 430; see also Ellen J. Staurowsky, "A Radical Proposal”: Title IX has No Role in College Sport Pay-for-Play Discussions, 22 MARQ. SPORTs L. ReV. 575 (2012) (quoting from the memoirs of Walter Byers, the first full-time executive director of the NCAA, that after the Nemeth decision that the NCAA intentionally crafted the term "student-athlete" to differentiate college athletes from those in the professional ranks and made a concerted effort to include the expression in all NCAA rules and interpretations); see also Matt Emeterio, Why Cam Newton Proves College Players Should Be Paid, PBH NeTwORK (Jan. 10, 2011), http://www.prosebeforehos.com/sportseditor/01/10/why-cam-newton-proves-college-players-should-be-paid/ (offering that after losing the Nemeth case, the NCAA created the "student-athlete" designation specifically to ensure that college athletes would not be deemed, at least linguistically, as employees of NCAA members universities and therefore not covered by state workers' compensation laws).

${ }^{40}$ State Comp. Ins. Fund v. Indus. Accident Comm'n, 314 P.2d 288 (Colo. 1957). It should be noted that workers' compensation was referred to as "workmen's compensation" in the actual case.

${ }^{41} I d$. at 289.

${ }^{42} I d$. at 290 (referring to Fort Lewis A\&M College, now known just as Fort Lewis College (in Durango), and the game against Trinidad State Junior College).

${ }^{43} \mathrm{Id}$. at 289 (noting that Dennison was not compensated in cash for his athletic scholarship, like his other university-related jobs, when it stated, "The benefit of the athletic scholarship was a waiver by the college of all tuition.").

${ }^{44}$ State Comp. Ins. Fund v. Indus. Accident Comm'n, 314 P. 2d 288 (Colo. 1957).

${ }^{45} \mathrm{Id}$. at 290 . The court also stated that it did not believe that the legislature intended the workers' compensation fund to be a "pension fund for all student athletes attending our state educational institutions."

${ }^{46} I d$. (quoting Univ. of Denver v. Nemeth at 426-27, "The football coach testified that meals and the job ceased when the student was "cut from the football squad."; see Nemeth, at 392 ("the employment at the University, so far as Nemeth was concerned, was dependent on his playing football, and he could not retain his job without playing football.”). 
In contrast, the Court was unable to find evidence that Dennison was under an obligation to do various work for the University in order to maintain his position on the football team. ${ }^{47}$

Just over a decade later, in 1974 Kent Waldrep, a running back for Texas Christian University (TCU), claimed that he, too, was a school employee following an injury that left him a paraplegic after a tackle he suffered during a football game against the University of Alabama. ${ }^{48}$ TCU ceased paying his medical bills after nine months. In a workers' compensation suit filed by Waldrep, the Texas Court of Appeals held that a student-athlete was not considered an "employee" of the university even though he was a scholarship recipient, thus delineating Waldrep's recovery under a workers' compensation claim. ${ }^{49}$

To this day, student-athletes in all sports are still not entitled to workers' compensation benefits under any state law, nor are they considered university employees per se under either federal or state labor law. ${ }^{50}$ Student-athletes have not yet successfully formed a union to bargain for rights since they are not considered employees, and courts have ultimately held steadfast against attempts

\footnotetext{
47 "[Dennison] was the beneficiary of an athletic scholarship known as a "Grant-in-Aid" to students; he was hired by the college to manage the student lounge; he also was hired to do work on the college farm; and received assistance from the G. I. Bill for ex-servicemen. As a regularly enrolled student, he was privileged to share in the student activities of the school, and was employed by the school as a part time employee and paid on an hourly basis of seventy cents per hour." Id. at 289.

${ }^{48}$ Waldrep v. Texas Emp'rs Ins. Ass'n, 21 S.W.3d 692 (Tex. Ct. App. 2000) (offering that a student-athlete like Waldrep was not considered an "employee" of the university although he was on scholarship, and therefore the student-athlete could not recover under workers' compensation after suffering a paralyzing football injury).

${ }^{49} I d$. Waldrep's case went on after years of appeals, but the Texas decision remained the same. Still, according to noted author Taylor Branch, in 1990 "the White House honored Waldrep's team of legislative catalysts at the signing ceremony for the Americans with Disabilities Act." See Taylor Branch, How the Myth of the NCAA "Student-Athlete" was Born, DEADSPIN (Feb. 20, 2014), http:// deadspin.com/how-the-myth-of-the-ncaa-student-athlete-was-born-1524282374 (offering, "The appeals court finally rejected Waldrep's claim in June 2000, ruling that he was not an employee because he had not paid taxes on financial aid that he could have kept even if he quit football.").

${ }^{50}$ At public universities, student-athletes would be governed by state labor laws. Under state law such as California, students who provide services for the universities they attend automatically qualify as "employees" when: a) "the services provided . . . are [un]related to their educational objectives"; b) "the students' educational objectives take a back seat to their service obligations."
} 
to characterize them as such. ${ }^{51}$ It is important to note that some courts have acknowledged the unique relationship between the student-athlete and their institution; however, such relationship has never been characterized as that of employer-employee. ${ }^{52}$

Although workers' compensation claims and the recent attempt by studentathletes have almost universally failed under the judicial system, it does not mean that student-athletes are void of other opinions, perspectives, voices and affairs that

51 See Univ. of Denver v. Nemeth, 257 P.2d 423 (Colo. 1953) (analyzing that a student fell under benefits of workers' compensation when he was employed by the university for work on campus tennis courts, was allowed time off to play football, and was injured during spring football practice; his injury was deemed to have arisen out of course of employment); but see State Comp. Ins. Fund v. Indus. Comm'n, 314 P.2d 288 (Colo. 1957) (offering that although the student-athlete received a scholarship covering his tuition to play football, and also worked a job on campus paying him $\$ .70 /$ hr., he was injured during the game, and evidence did not establish that at the time of his injury he was under contract to play football, or that employment by the college was the cause of his injury; thus, he could not recover workers' compensation benefits); Van Horn v. Indus. Accident Comm'n, 33 Cal. Rptr. 169 (Cal. Ct. App. 1963) (Evidence showed that student-athletes who received athletic scholarships may be deemed employees of university, and family members could recover under Workmen's Compensation Act, when a student-athlete was fatally injured in plane crash while traveling home from game with the football team); Rensing v. Ind. State Univ. Bd. of Trs., 444 N.E.2d 1170 (Ind. 1983) (Student-athlete on scholarship to play football and university do not have employee-employer relationship, and thus, student-athlete could not recover benefits under workers' compensation after being injured); Coleman v. W. Mich. Univ., 336 N.W.2d 224 (Mich. Ct. App. 1983) (Injured football player was denied benefits under workers' compensation because student-athlete receiving scholarship did not constitute "wages" under meaning of Workers' Disability Compensation Act);

${ }^{52}$ Kleinknecht v. Gettysburg Coll., 989 F.2d 1360 (3rd Cir. 1993) (holding that college owes student-athlete a duty of care based on special relationship between college and player given his capacity as an athlete of the school and his participation in a sport for which he was recruited to play by the team's coach; college was required to take reasonable precautions to protect against risk of reasonably foreseeable life-threatening injuries while participating in athletic events); Orr v. Brigham Young Univ., 108 F.3d 1388 (10th Cir. 1997) (holding that no special relationship exists between university and football player such that he could bring a claim alleging breach of duty of care based on that relationship); Korellas v. Ohio State Univ., 779 N.E.2d 1112 (Court of Claims of Ohio 2002) (holding that student-athlete on university football team was not employee of school, and as such, could not receive immunity in civil action arising out of assault of food delivery man; football player only received scholarship money but no money directly to himself); Kavanagh v. Trs. of Bos. Univ., 795 N.E.2d 1170 (Mass. 2003) (opining that college basketball player who was punched during game by opposing player could not bring action against opposing coach and opposing university because opposing player was not an employee or servant of university, and coach did not have special relationship with player giving him a duty to protect injured player from the assault and battery); Cope v. Utah Valley State Coll., 290 P.3d 314 (Utah App. 2012), rev'd and remanded, 342 P.3d 243 (Utah 2014) (holding that a dance team member at college who sustained head injury during rehearsal could bring action against college because coach created a special relationship with student-athlete by instructing her to do a lift, such that college owed her a duty of care); Kennedy v. Syracuse Univ., 94-CV-269, 1995 WL 548710 (N.D.N.Y. Sept. 12, 1995) (holding that an injured student-athlete could not bring negligence or breach of contract claims against university when student injured wrist participating in gymnastics practice because school owed him no special duty, even though contractual relationship existed between student-athlete and university as he was a scholarship athlete, and there was no causal relationship between plaintiff's injuries and university's alleged lack of medical personnel on scene). 
are significant to them. As the article demonstrates, there have been decades of activism and mobilization efforts led by professional, amateur, and student-athletes who have expressed opinions about perceived injustices in efforts to induce change. ${ }^{53}$

\section{Racial and Political Unrest in Sports: Precursor to Student- Athlete Activism}

During the 1960s, the Civil Rights Movement was at the forefront of national discussion in the U.S., including within the context of sports. ${ }^{54}$ The enactment of the Civil Rights Act of 1964 represented significant change in the U.S., a country which has had a long history, particularly in the South, of discriminatory practices against non-whites. ${ }^{55}$ The advent of the Vietnam War during that same time period caused additional social and political unrest and activism across the U.S. resulting in serious and outspoken protestors, some of whom included high school and college students. ${ }^{56}$

Boxer Cassius Clay (later known as Muhammad Ali), for example, refused to enlist in the military as a result of his conscientious objection to the Vietnam War in 1967. ${ }^{57}$ In 1968, John Carlos and Tommie Smith, who won the gold and bronze medals respectively in the 200 meter dash, paid a price for raising black power fists at the 1968 Mexico City Summer Olympics while on the medal podium as

\footnotetext{
${ }^{53}$ See Dave Zirin, The Missouri Tigers and the Hidden History of Black College Football Activists, NATION (Nov. 12, 2015), http://www.thenation.com/article/the-missouri-tigers-and-the-hiddenhistory-of-black-college-football-activists/ (offering, e.g., that in 1967, 35 black players on the University of California-Berkeley, football team boycotted spring practice until more black coaches were hired. As a result, John Erby was soon thereafter named as the first black assistant coach; see also EAB [Education Advisory Board], Increasingly, Student-athletes Become Student Activists (Nov. 11, 2015), https://www.eab.com/daily-briefing/2015/11/11/student-athletes-increasinglybecome-student-activists (outlining various examples of student activism including in 2015 when the University of Oklahoma's football team refused to practice for a week after a video of members of the local Sigma Alpha Epsilon chapter singing a racist song went viral).

${ }^{54}$ See Samuel G. Freedman, The Civil Rights Legacy that Led to Mizzou, Vice SPORTs (Nov. 10, 2015), https://sports.vice.com/ca/article/the-civil-rights-legacy-that-led-to-mizzou (characterizing 1960s as one of the "Civil Rights and Black Nationalist Movements.").

55 See CNN, The Civil Rights Movement, http://www.cnn.com/EVENTS/1997/mlk/links.html (offering a timetable involving the civil rights struggle in the U.S.).

56 See, e.g., Ian Wilhelm, Ripples from a Protest Past, Chron. Higher Educ. (Apr. 17, 2016), http://chronicle.com/article/Why-an-Armed-Occupation-of/236133?key=yX8stQ9HjaiC65yUzOZEf3V8ySRpZyt_GgoyhdRt6xEZnlpZUpDbjVES3lid0tCNDVYYmJscUN2bFhlMjR0WHp3UUFYUm9kWS1z (discussing how in 1969 an armed occupation by black students sent Cornell's campus into chaos); see also generally Penn State University Libraries, Years of Crises: The 1960s, https://www.libraries.psu.edu/psul/digital/pshistory/bezilla/1960s.html; see also Tinker v. Des Moines Indep. Cmty. Sch. Dist., 393 U.S. 503 (1969) (deciding that two high school students who protested the Vietnam War by wearing armbands to school had the right to wear them as long as there was not a substantial disruption to or interference with school activities. "It can hardly be argued that either students or teachers shed their constitutional rights to freedom of speech or expression at the schoolhouse gate.").

${ }^{57}$ See Craig Hlavaty, 48 Years Ago Today, Muhammad Ali Refused the Draft in Houston, CHron. сом (Apr. 28, 2015), http://www.chron.com/news/houston-texas/article/48-years-ago-todayMuhammad-Ali-refused-the-5435356.php.
} 
the National Anthem was being played. ${ }^{58}$ Carlos and Smith reflected the feeling of many Americans at the time of civil unrest in the U.S. ${ }^{59}$ As a result of their rebellious behavior, both runners were ejected from the U.S. Olympic team and sent home. ${ }^{60}$

A few years later, led by American iconic runner Steve Prefontaine, a former NCAA champion from the University of Oregon, and others' discontent with regard to the stringent amateurism rules in track and field which disallowed sponsorships and appearance fees, this turned into public protests. ${ }^{61}$ At that time, the contentious struggle for power in amateur sports, particularly between the Amateur Athletic Union (AAU) and the United States Olympic Committee, ultimately led to the enactment of the Amateur Sports Act of 1978 and its modification twenty years later, giving a more powerful voice to amateur and Olympic athletes than had ever been available before. ${ }^{62}$

Also during the mid-1970s, Major League Baseball (MLB) player Curt Flood, refusing to accept his trade from the St. Louis Cardinals to the Philadelphia Phillies, filed a lawsuit that went all the way to the U.S. Supreme Court, alleging that baseball's reserve clause constituted a form of modern day slavery. ${ }^{63}$ Flood, who vehemently opposed being characterized as a piece of property that could be traded like a slave, ultimately lost his legal battle. ${ }^{64}$ However, his public action drew national attention, ultimately resulting in MLB changing its rules regarding the reserve clause in 1975, an action that other major professional sports leagues adopted soon thereafter. ${ }^{65}$

Though the 1960s and 1970s represented tumultuous times with regard to civil rights in the U.S. at the professional and Olympic sport levels, this era also represented some of the most effective mobilization efforts by student-athletes at colleges and universities around the country with regard to their opinions of racial injustice as well. Numerous examples of unrest among student-athletes in football

\footnotetext{
${ }^{58}$ See David Davis, Olympic Athletes Who Took a Stand, Smithsonian.com (Aug. 2008), http:// www.smithsonianmag.com/people-places/olympic-athletes-who-took-a-stand-593920/?no-ist (noting that the inspiration for the Olympic black power fist protest was inspired by Harry Edwards, a sociologist teaching at San Jose State University at the time, the same institution where Smith and Carlos were students).

${ }^{59} \mathrm{Id}$.

${ }^{60}$ Id.; see also Frank Litsky, Wayne Collett, Track Medalist Barred Because of a Protest, Dies at 60, N.Y. Times (Mar. 18, 2010), http://www.nytimes.com/2010/03/18/sports/18collett.html (authoring that both Wayne Collett and Vincent Matthews were kicked out of the 1972 Munich Olympics for their behavior on the medal stand akin to the actions of Carlos and Smith in 1968).

${ }^{61}$ See Mary Pilon, Steve Prefontaine's Last Run, GrantLand (May 29, 2015), http://grantland. com/features/steve-prefontaine-death/; see also Steve Bence, College Football Needs a Prefontaine, Says Ex-Oregon Runner Who Defied NCAA, OREGONLive.com (May 2, 2011), http://www. oregonlive.com/ducks/index.ssf/2011/05/college_football_needs_its_own.html.
}

${ }^{62}$ See Branch, supra note 14; see also Ted Stevens Olympic and Amateur Sports Act of 1998 (TSOASA), 36 U.S.C. § 220521 et seq. (2016); Adam Epstein, Go for the Gold by Utilizing the Olympics, 29 J. Legal Stud. Educ. 313, 315-326 (2012) (referencing the TSOASA, the 1998 law governing athlete rights, disputes and mandating that U.S. Olympic-related disagreements must be resolved via arbitration rather than litigation).

${ }^{63}$ Adam Epstein, Sports Law 350-51 (2013).

${ }^{64} \mathrm{Id}$.

${ }^{65}$ Id.; see also Chris Isadore, Legacy of a Well-paid Slave, CNNMoneY.com (Nov. 20, 2006), http://money.cnn.com/2006/11/20/commentary/sportsbiz/. 
resulted in protests that had an impact on their team, coaches, administrators and their opponents as well during the civil rights era. However, organizing for change by way of speech and protest are not confined to the 1960s and 1970s alone.

The next subsection provides examples of student-athletes' personal attempts to change the status quo. It appears that throughout history there have been two major areas in which student-athletes have used the power of speech and activism to contest and bring attention to perceived injustices: (1) racial (and sometimes political) discrimination, and (2) lack of compensation for services rendered (also characterized as claims for economic injustice due to commercial exploitation). ${ }^{66}$ The following section provides illustrations of these two areas.

\section{The Birth of Collective College Athlete Action}

Although the Civil Rights Movement and Vietnam War played significant roles in prompting vocal activism across many genres within the U.S., student-athlete social activism began taking shape much earlier. Beginning in the 1930s at the University of Michigan and extending into the current age of unified mobilization efforts using social media outlets, the intercollegiate sports arena has a deep history of racial, political, and economic dissatisfaction resulting in continuous and evolutionary change.

The Willis Ward Racial Protest in Ann Arbor. One of the earliest examples of public dissatisfaction and activism led by student-athletes in an effort to quash inequitable racial treatment spawned from a football game between the University of Michigan and Georgia Tech on October 20, 1934. ${ }^{67}$ The game took place at Michigan Stadium (the Big House), but one of Michigan's players, Willis Ward-a future federal judge - was asked not to participate because of his African-American heritage. ${ }^{68}$ In fact, Georgia Tech actually threatened to forfeit the game if Ward played, and Michigan eventually agreed to their opponent's demands. ${ }^{69}$

\footnotetext{
${ }^{66}$ See Patrick Hruby, Four Years a Student-Athlete: The Racial Injustice of Big-time College Sports, VICE.COM (Apr. 4, 2016), https://sports.vice.com/ca/article/four-years-a-student-athlete-the-racialinjustice-of-big-time-college-sports (maintaining that though there is "nothing inherently racist about amateurism itself," and that "the economic exploitation within college sports remains raceneutral on its face," that the impact of the NCAA's policies have an unjustified, adverse impact on blacks. In fact, Hruby demonstrates that not only does the hundreds of millions of dollars that the NCAA generates not go to the predominantly black athletes who play the big-time Division I sports of football and men's basketball, but in fact the majority of the cash "...largely ends up in white pockets." Hruby offers that in the 2016 men's NCAA national championship game, the head coaches of the University of North Carolina and Villanova University, both white, earn \$2 million and \$2.5 million a year, and the white NCAA president, the five power conference commissioners, and head coaches in football in the ACC and SEC make millions in addition to the University of Alabama's strength coach, who is also white, makes over $\$ 600,000$ per year).

${ }^{67}$ See Black and Blue- The Story of Gerald Ford, Willis Ward and the 934 MichiganGeorgia Tech Game (2011). Michigan won 9-2, though it was their only victory that entire season in which they went 1-7 overall.

${ }^{68} \mathrm{Id}$.

${ }^{69} \mathrm{Id}$.
} 
Initially in response to this agreement, future President Gerald Ford (then a fellow teammate of Ward) and other Michigan teammates initiated a protest, refusing to play in the game and threatening to quit the team. ${ }^{70}$ Ward, however, encouraged Ford to play while the sole African-American Wolverine spent the day listening to the game from the confines of his fraternity house rather than sitting in the stadium cheering his team on to victory. ${ }^{71}$

In 2012 Ward, Ford and this historic event were recognized at Michigan Stadium. ${ }^{72}$ The fact that Ford and other players initiated a verbose protest against benching an African-American teammate based on race represented one of the earliest examples of student-athlete mobilization efforts, though such efforts did not ultimately lead to Ward's participation in the game. ${ }^{73}$

The Howard University Food Boycott. Throughout its history, Howard University (Howard), an historically black college and university (HBCU), has had several instances of student-athlete activism. In 1927, Howard halted all food, housing and tuition payments made to the members of its football team, resulting in players threatening to strike and refusing to play until such payments were reinstated. ${ }^{74}$ In this circumstance, the mere threat of a strike was successful, and Howard reinstated the payment plans without disruption to the football season. ${ }^{75}$

Later, in 1936 Howard football players refused to play in a scheduled game against Virginia Union, alleging that Howard failed to provide them with food prior to or after the game. ${ }^{76}$ In a Time magazine report from that period, one Howard player stated, "We were too hungry to get in there and battle those big country boys full of ham and kale." "77 Howard students ultimately joined forces with football players, and boycotted classes to march down Washington DC's Georgia Avenue chanting, "Food! Food! Food! We want food!", and carrying signs reading, "We Want Ham and Cabbage for the Team!"’78

\footnotetext{
${ }^{70} I d$.

${ }^{71} \mathrm{Id}$.

${ }^{72} \mathrm{Id}$.

${ }^{73}$ Id.; see also John Shearer, President Ford Made a Stand for His African-American Friend, Chattanoogan.com (Jan. 5, 2007), http://www.chattanoogan.com/2007/1/5/99293/PresidentFord-Made-A-Stand-For-His.aspx; see also generally, David K. Wiggins, "Strange Mix of Entitlement and Exploitation”: The African American Experience in Predominantly White College Sport, 2 Wake Forest J. L. \& POL'y 95, 102 (2012) (noting that Georgia Tech refrained from using its star end Hoot Gibson).

${ }^{74}$ See Patrick Hruby, Unionize College Athletics, SportsOnEarth.com (Apr. 8, 2013), http:// www.sportsonearth.com/article/44209014/ (offering, too, that in 1940, the Stanford football team demanded and received $\$ 50$ per player to compete in the Rose Bowl).

${ }^{75} \mathrm{Id}$.

76 See Dave Zirin, ESPN is Wrong: Grambling State Isn't the First College Team to Fight Back, Nation (Oct. 21, 2013), http://www.thenation.com/article/ espn-wrong-grambling-state-isnt-first-college-team-fight-back/.

${ }^{77} \mathrm{Id}$.

${ }^{78} \mathrm{Id}$.
} 
This show of activism was regrettably without irony - the student-athletes were literally being denied food by their university. ${ }^{79}$ Howard's reputation for failing to feed athletes appeared again in the 1980s when a star Howard football player contacted the Washington Post, claiming that he had to play hungry because Howard refused to add him to the university meal plan. ${ }^{80}$ Following the whistleblower's expulsion from school due to his statements to the newspaper, the Washington Post published a series of stories about the mistreatment of Howard athletes (much of which entailed deprived feedings), eventually leading to a large-scale boycott by student-athletes at the 1981 Howard athletic banquet. ${ }^{81}$

Likewise, in May of 1968, Howard student-athletes again rallied to express discontent about their circumstances. ${ }^{82}$ In this instance, student-athletes threatened to quit playing for their various sports teams unless Athletic Director (AD) Samuel Barnes was fired. ${ }^{83}$ Student-athletes further demanded, "better food, more medical attention, streamlined means of transportation, more equipment, better living conditions and a full-time sports information director." 84 Then the student assembly president, Ewart Brown Jr., a member of the track team, burned his Howard varsity sweatshirt in protest, stating "This is what we think of the athletic program. [We need a] cremation of the old system." 85 Howard is not the only university that experienced early staged protests led by studentathletes; however, its history is noteworthy since the 1968 threats led to the loss of the AD's job. ${ }^{86}$

\footnotetext{
${ }^{79}$ See Dave McKenna, Athletes Don't Go to Howard University for the Food!, WASH. CiTy PAPER (Dec. 10, 2010, 2:15PM), http://www.washingtoncitypaper.com/blogs/citydesk/2010/12/10/ athletes-dont-go-to-howard-university-for-the-food/.

${ }^{80} \mathrm{Id}$.

${ }^{81} \mathrm{Id}$.

${ }^{82}$ See Dave Zirin, supra note 76.

${ }^{83} \mathrm{Id}$.

${ }^{84} \mathrm{Id}$.

85 Id.; see also Dave Zirin, Hidden History of Strikes and Other Protests in College Sports, ZinnedProject.org (Oct. 29, 2013), http://zinnedproject.org/2013/10/ hidden-history-of-strikes-protests-college-sports/.

${ }^{86}$ See Zirin, supra.
} 
The University of Wyoming 'Black 14'. On October 17, 1969 at the University of Wyoming, 14 of the football team's African-American players were expelled from the team because they wanted to wear armbands in a game scheduled against Brigham Young University (BYU) in protest to the racial discrimination at BYU and within the Mormon Church. ${ }^{87}$ The Wyoming Cowboys were unbeaten and ranked twelfth in the nation at the time. ${ }^{88}$

The players, who referred to themselves as the Black 14, were dismissed the night before the home game in Laramie and later unsuccessfully sued their head coach in federal court for $\$ 1.1$ million in damages with the support of a law firm from Michigan that had worked with the National Association for the Advancement of Colored People (NAACP). ${ }^{89}$ Lloyd Eaton, the head football coach-turned-defendant for the University of Wyoming, believed that his team was targeted and greatly influenced by the Black Student Alliance on campus due to a

${ }^{87} \mathrm{Id}$; Zirin offers that BYU is affiliated with the Mormon Church and denied leadership positions
to African-Americans based upon the assertion that dark skin was "the mark of the curse of Ham.";
see also Freedman, supra note 54 (stating that "in the early 2000s the University of Wyoming
reconciled with the Black 14."). Freedman also offers another example of a racially-based protest
involving student-athletes by the South Carolina State football team and its coach Oree Banks
against segregation off the campus in Orangeburg, South Carolina. This led to the death of a local
high school player in an incident on February 8,1968 in what became known as the Orangeburg
Massacre. See Samuel G. Freedman, 45 Years Ago, a Stand That Turned Deadly, N.Y. TimES (Feb.
7, 2013), http://www.nytimes.com/2013/02/08/sports/ncaafootball/south-carolina-state-stand-
unmatched-by-any-made-on-a-field.html.

${ }^{88}$ See Phil White, The Black 14: Race, Politics, Religion and Wyoming Football, WyoHistory. ORG, http://www.wyohistory.org/essays/black-14-race-politics-religion-and-wyoming-football; see also Zirin, supra note 85; Freedman, supra note 54. Zirin states, "After similar rumblings rose at Stanford University, President Kenneth Pitzer announced in November of 1969 that he would honor what he called an athlete's "right of conscience." It would allow athletes to boycott schools or event that he or she deemed 'personally repugnant.' It made a serious impact."

${ }^{89}$ See Williams v. Eaton, 310 F. Supp. 1342 (D. Wyo. 1970), aff'd in part and vacated in part 443 F.2d 422 (10th Cir. 1971), aff'd 468 F.2d 1079 (10th Cir. 1972) (upholding the suspension of the football players in that it was "a reasonable regulation" of speech-related expression under the circumstances involved." BYU is owned and operated by the Church of Jesus Christ of Latter-Day Saints, and Lloyd Eaton was the head football coach for Wyoming.); see also Douglas Ernst, Arkansas Running Back Strikes 'hands up, don't shoot' Pose after TD, WASH. Times (Nov. $28,2014)$, http://www.washingtontimes.com/news/2014/nov/28/jonathan-williams-arkansasrazorbacks-rb-makes-han/ (offering that during the 2014 football season, University of Arkansas running back Jonathan Williams scored a touchdown against the University of Missouri, dropped the football and raised his hands in the "hands up, don't shoot" sign often seen after the shooting of Michael Brown in Ferguson, Missouri); see also James E. Barrett, The Black 14: Williams v. Eaton

A Personal Recollection, UWyo.EDU, http://www.uwyo.edu/robertshistory/barrett_black_14.htm (noting that Barrett was part of the case and retired as a Senior Judge on the United States Circuit Court of Appeals, Tenth Circuit). 
rule against demonstrations. ${ }^{90}$ Although the Black 14 did not appeal the decision the U.S. Supreme Court, it is interesting to note that in 1978 the Mormon Church ultimately changed the racially-based policy against blacks, the one the Wyoming players had protested..$^{91}$

Armbands in Solidarity. In the late 1960s, San Jose State University was also a hotbed for protest among student-athletes and others. Actually, in the 1960s and 1970s, it was not uncommon for student-athletes to repeatedly voice their opinions independent of the coaches and administration. ${ }^{92}$ For example, when BYU was scheduled to play football against San Jose State on October 25, 1969, the Spartans wore black armbands in support of Wyoming's Black $14 .{ }^{93}$ Dissatisfied with the mobilization at Wyoming, other Western Athletic Conference (WAC) schools demanded that Wyoming be dropped from their college football schedule, though it did not result in that outcome. ${ }^{94}$

Prior to the Wyoming Black 14 incident, San Jose State University studentathletes displayed armbands in solidarity against racism within the Fraternal Greek system at school and local business establishments. ${ }^{95}$ Similarly, after student-athletes threatened to refuse to play in the opening game of the 1967 college football season against the University of Texas-El Paso due to protest racism, San Jose

\footnotetext{
90 See Pat Putnam, No Defeats, Loads of Trouble, SI.com (Nov. 3, 1969), http://www.si.com/ vault/1969/11/03/611044/no-defeats-loads-of-trouble (writing that head football coach "Eaton insists that his players act as individuals and not as factions, which he feels splits the team, and he became incensed when the Negro players appeared before him that morning as a group.").

${ }^{91}$ See Zirin, supra note 85; see also Wiggins, supra note 73, at 108-109; see also John Henderson, Spirit of the Black 14, Denver Post (Nov. 8, 2009), http://www.denverpost.com/ci_13739558 (offering that the Mormon Church did not allow African-Americans into the priesthood, but that a year after the game, the first African-American played for BYU and then in 1978, the Mormon Church dropped its policy regarding blacks and priesthood).

${ }^{92}$ See Zirin, supra note 53; see also Tom Goldman, A Deep-Rooted History of Activism Stirs In College Football, NPR.org (Nov. 10), 2015, http://www.npr.org/2015/11/10/455462047/a-deeprooted-history-of-activism-stirs-in-college-football (writing that student-athlete protests were common during this era, and quoting historian Lane Demas, a professor at Central Michigan University, "There's a three-year period of roughly 1967 to 1970 when there really was a wave of black football protest that coincided with kind of the general student movement on college campuses ...").

${ }^{93}$ Id. Even though Wyoming beat BYU 40-7 the previous week and San Jose State without the suspended players, Wyoming lost its final four games that season in 1969. After then going 1-9 the next year, Wyoming fired Eaton. See WikiPedia, 1969 Wyoming Cowboys Football Team, https://en.wikipedia.org/wiki/1969_Wyoming_Cowboys_football_team.

${ }^{94}$ Putnam, supra note 90.

95 Goldman, supra note 92.
} 
State University's president Robert Clark actually canceled that game to avoid confrontation, and the New York Times called it unprecedented: the first college game canceled due to "racial unrest."96

Amidst this dark period of racial and political unrest and protests between student-athletes and their institutions, other landmark events occurred which helped shape the development of the student-athlete activist movement. In 1967, for example, thirty-five University of California, Berkeley football players boycotted spring

${ }^{96}$ Id.; see also Lane Demas, Surprised that College Football Players Tackled Bigotry on Campus? Here's Why You Shouldn't Be, HeCHINGER REPORT, http://hechingerreport.org/surprised-thatcollege-football-players-tackled-bigotry-on-campus-heres-why-you-shouldnt-be/. Demas notes that Governor Ronald Reagan was not pleased with the planned boycott by the players but was even more incensed at the decision of the university president Clark. Demas also offers that San Jose State is also where American sprinters John Carlos and Tommie Smith of the 1968 Mexico City Olympic Games attended. Demas then offers that from 1967-1970, there were numerous other examples of student-athlete activism including, but not limited to, "The University of Washington football team briefly suspended all 13 of its African American players after they refused to take a loyalty oath mandated by the coach. Fourteen black players were dismissed from Indiana University's team after boycotting practices, claiming the climate on campus was "mentally depressing and morally discouraging to blacks." Fourteen at the University of California, Berkeley, refused to practice over scholarship support and accusations of stacking. At Iowa State University, 24 black athletes submitted a list of grievances, including demands that the school hire more black coaches and administrators; two football players refused to play and left the team. Thirty-eight footballers at Michigan State University held a one-day strike, as did nine at Syracuse University. Football protests even infiltrated the Ivy League, where athletics were supposedly de-emphasized in the name of austere academics. Five players at Princeton University made national headlines when they publicly accused the coach of racism." For further discussion of the 1970 incident involving the "Syracuse Nine," see William C. Rhoden, Syracuse Honors Nine Players Who Took a Stand, N.Y. Times (Oct. 22, 2006), http://www.nytimes.com/2006/10/22/sports/ncaafootball/22rhoden. html?_r=0 (offering that on "May 1970, nine African-American football players at Syracuse University boycotted spring practice to protest what they viewed as racial discrimination and insensitivity in the program headed by its longtime coach, Ben Schwartzwalder." Rhoden also notes that at the time, they were actually known as the Syracuse Eight because "news media were unaware that an injured athlete was also involved in the boycott.”) 
practice due to a lack of African-American coaching staff. ${ }^{97}$ One year later, in 1968 players at Michigan State University delivered a list of demands to their AD, Biggie Munn, refusing to play football unless a search was conducted for African-American coaches, trainers, and cheerleaders. ${ }^{98}$ Twenty-four players walked out of spring practice as a result of Munn's refusal to comply. ${ }^{99}$ In 1972, the University of Washington Huskies football team refused to take the field for the second half of their homecoming game unless a protest statement was read over the stadium sound system opposing the Vietnam War. ${ }^{100}$ Such championing of early efforts by student-athletes-successful or not-laid the groundwork for the next phase of activism.

\section{Transitioning into the $21^{\text {st }}$ Century: The Evolution of the Student-Athlete Activist Movement}

After the Vietnam War, student-athlete-led protests relaxed to a great degree until the mid-1980s when collective college athlete action began taking shape again. In 1985 former Duke University basketball player Dick DeVenzio wrote the book, "Rip-Off U: The Annual Theft and Exploitation of Major College Revenue Producing Student Athletes," criticizing the NCAA and its amateurism model that prevented studentathletes from being paid. ${ }^{101}$ DeVenzio organized a student-athlete advocacy group known as the Revenue Producing Major College Players Association from his North Carolina residence, mailing newsletters to 300 college athletes. ${ }^{102}$ In fact, DeVenzio asked University of Oklahoma and Nebraska players to delay the start of a football game against Nebraska in Lincoln on November 22, 1986. ${ }^{103}$ In response, five players from each team knelt down together at midfield, intending to draw attention to solidarity, athlete's rights, and allegations of the exploitation of student-athletes. ${ }^{104}$

${ }^{97}$ Zirin, supra note 53.
${ }^{98}$ Id.
${ }^{99}$ Id.; see also John Matthew Smith, "Breaking the Plane”: Integration and Black Protest in Michigan State University Football during the 1960s, Michigan Historical Rev. (Sept. 22, 2007), https://www.highbeam.com/doc/1G1-172597475.html (offering that the Big Ten Conference, Michigan State and Coach Munn in particular were leaders of integration, stating, "By 1966, MSU fielded so many black players that the team was often compared to those of Historically Black Colleges and Universities like Grambling, Florida Agricultural and Mechanical, and Morgan State.").

100 Zirin, supra note 53; see also Evin Demirel, College Football's Loud 'No Comment', ClasSICAL.ORG (Dec. 30, 2014), http://theclassical.org/articles/college-footballs-loud-no-comment (offering that the following was broadcast throughout the stadium, "Ladies and gentlemen, may we have your attention for a very important announcement: The football team at the University of Washington wishes to take this moment to express its concern over the present situation in Vietnam. Toward this end, the team will now delay the game for a couple of minutes.").

${ }^{101}$ Hruby, supra note 74.

102 Id.

103 Id.; see also Roy S. Johnson, Oklahoma Rallies and Earns Berth in Orange Bowl, N.Y. TIMES (Nov. 23, 1986), http://www.nytimes.com/1986/11/23/sports/college-football-oklahoma-ralliesand-earns-berth-in-orange-bowl.html.

104 Id. 
In 1987, a federal civil rights case arose out of a dispute involving Washburn University's 1986 football season when several African-American football playerturned plaintiffs complained that they were being treated in a racially-discriminatory manner by the coaches and administrators in violation of federal laws. ${ }^{105}$ As noted by the court, ". . . many also felt that white players on the team were being favored by the coaching staff and that lesser white players had been awarded better scholarships than some of the black players." 106 After a meeting with the administration, including school president John L. Green, the African-American players boycotted team practices in August, 1986, resulting in the administration removing those players from the team after refusing to apologize for the boycott. ${ }^{107}$ It was later discovered that head coach Larry Elliott had a policy that allowed "an absence protesting racial mistreatment" to qualify as an excused absence. ${ }^{108}$ Still the federal district court hearing the case found that the university was not liable for removing the players from the team because there was no breach of contract nor a property interest in playing college football. ${ }^{109}$

Two decades later, on October 19, 2013 Grambling State University cancelled its football game against Jackson State after players refused to show up for their bus ride to Jackson, Mississippi in protest against head coach Doug Williams' firing that September, poor facilities, and lengthy travel conditions. ${ }^{110}$ The boycott ultimately led to a $\$ 20,000$ conference fine for game cancellation, as well as a promising $\$ 32,000$ investment in the athletic weight room. ${ }^{111}$ Players claimed that unsanitary locker room conditions, including mildew and mold on the ceilings,

\footnotetext{
${ }^{105}$ Hysaw v. Washburn Univ. of Topeka, 690 F. Supp. 940, 942 (D. Kan. 1987). The players claimed that the university infringed upon their free speech, liberty and property rights in violation of 42 U.S.C. $§ 1983,42$ U.S.C. $§ 1981$, and breached their athletic contracts with Washburn University. The defendants were the president of the university, the athletic director Jerry Robertson and head football coach, Larry Elliott.
}

${ }^{106} I d$.

${ }^{107} I d$. at 943 (Robertson told them that they would be allowed to retain their scholarships if they met the following conditions: 1) issue an apology through the news media to Washburn and its administration, 2) apologize to the football team at a team meeting, 3) participate in five early morning practices, 4) agree to be kept out of the first game that season, and 5) "exhibit total commitment and support to the Washburn University football program.”).

${ }^{108} I d$.

${ }^{109} I d$. at 946-47 ("Plaintiffs argue they were promised that they would be allowed to play football during the 1986-87 season. Yet the written scholarship contracts they signed make no indication of such promises. In fact, the only promises in those written contracts were that the players would receive money. Plaintiffs provide no other evidence, other than "understandings" and "expectations", that they were promised a position on the 1986 team.).

110 See Sean Isabella \& Daniel Uthman, After Grambling Player Revolt, Game at Jackson State Canceled, USA TodAY (Oct. 19, 2013), http://www.usatoday.com/story/sports/ncaaf/ swac/2013/10/18/grambling-tigers-bus-jackson-state-game-boycott/3010079/.

${ }^{111} I d$. (quoting Ramogi Huma, president of college athlete advocacy group the National College Players Association, "They've come together to identify various issues to have their voices heard."). 
walls, and floor led to cases of staph infections. ${ }^{12}$ Grambling State played out the remainder of the football season following that forfeit. ${ }^{113}$

In December 2014, at the end of the college football season, the entire University of Alabama-Birmingham (UAB) football program was cancelled in a decision ultimately made by the University President, Ray Watts. ${ }^{114}$ The unilateral decision was later reversed in 2015 following numerous and passionate protests by faculty, students, student-athletes and alumni. ${ }^{115}$ In fact, the bylaws of Conference USA, of which UAB is a member, required its schools to have a football program, and the loss of affiliation with the Conference would have cost UAB significant funds. ${ }^{116}$ Had UAB moved forward with the cancellation, it would have been the first major college football program to shut down since Pacific University in 1995. ${ }^{117}$

In 2015, protests led by student-athletes against head football coach Tim Beckman at the University of Illinois led to his eventual termination. ${ }^{118}$ In a separate mobilized effort, male college basketball players at William Paterson University (WPU) walked off the court prior to the start of their game against Ramapo College,

\footnotetext{
112 ESPN.com News Services, Grambling Responds to Concerns, ESPN.com (Oct. 20, 2013), http://espn.go.com/college-football/story/_/id/9846943/grambling-state-tigers-playerssend-letter-complaint-administration.
}

${ }^{113}$ ESPN.com News Services, Grambling Players End Boycott, ESPN.com (Oct. 22, 2013), http:// espn.go.com/college-football/story/_/id/9858903/grambling-state-tigers-players-end-boycottpracticing. A full copy of the complaint is available at http://a.espncdn.com/pdf/2013/1019/ Grambling_State_Football_Complaints.pdf, on file with the authors.

${ }^{114}$ See Pete Volk, 5 Most Ridiculous Things about UAB's Football Shutdown Memo, SBNATION. COM (Mar. 27, 2015), http://www.sbnation.com/college-football/2015/3/27/8289125/uab-footballprogram-canceled-ray-watts (offering that so to was the rifle team and women's bowling teams).

${ }^{115}$ See Jake New, Too Big to Fail?, InsideHigherEd.com (June 4, 2015), https://www.insidehighered.com/news/2015/06/04/u-alabama-birmingham-learns-how-difficult-it-sack-college-football (writing that soon after Watts decision that the university's Faculty Senate gave a vote of no confidence and passed a resolution showing its "full support" for college athletics).

116 Id.

${ }^{117}$ Id.; see also Jon Solomon, UAB Football is Back, Future Questions Remain about Reinstatement, CBS SPORTS.COM (June 1, 2015), http://www.cbssports.com/collegefootball/writer/jonsolomon/25201823/sources-uab-football-is-back-reinstatement-announcement-monday (stating, "About $56 \mathrm{UAB}$ football players transferred to other schools after the program was eliminated last December. They picked up their lives and moved on somewhere else -- only to now see UAB football return six months later.").

118 See Vinnie Duber, Tim Beckman Saga Shows Importance of Student-athlete Voice, CSNCHICAGO.com (Aug. 28, 2015), http://www.csnchicago.com/big-ten/tim-beckman-saga-showsimportance-student-athlete-voice (authoring that Illinois football player Simon Cvijanovic "wanted his voice and the voices of other student-athletes to be heard." This led to Beckman being fired for his bullying behavior, including poor treatment and "forcing them to play injured" out of fear of having their scholarships revoked). The case was eventually settled so as to avoid a lawsuit, and Illinois paid Beckman $\$ 250,000$ to end the saga. Interestingly, Beckman forfeited the $\$ 3.1$ million remaining on the remaining two years of his five-year contract and the $\$ 743,000$ if his contract had been bought out. See Julie Wurth, Beckman to Get \$250,000 in Settlement with UI, News-Gazette (Apr. 12, 2016), http://www.news-gazette.com/news/local/2016-04-12/beckmanget-250000-settlement-ui.html. 
leaving their warmup shirts in a pile on the court and resulting in a forfeit game following the firing of Jose Rebimbas, their head coach who held a two decade track record of almost 400 wins at WPU. ${ }^{119}$

These more recent examples emphasize the continued strength and power of student-athletes in influencing their institutional environments. As modern society has transitioned into a virtual culture, the evolution of collective college athlete action has led to the adoption of social media to garner broader attention, prompting vocal protests and debates on a nationalized scale. The next section analyzes two recent and high-profile student-athlete mobilization efforts that gained substantial media attention, prompting national discussions and examinations about the relationship between the power of student-athletes and the institutions they represent. Such student-athlete-led efforts set the stage for the future of student activism and mobilization efforts in an era of media sensation.

\section{Northwestern University and the University of Missouri-The Future Is Now}

As discussed, since the 1930s unified mobilization efforts led by student-athletes helped bring controversial issues of race, politics, and economics to the forefront of evolutionary change in the U.S. However, prior to the advent of the Internet notoriety of these historic efforts were generally contained to local news arenas. The inception of the Internet and subsequent surge of social media outlets has launched a new wave of highly-visible mobilization efforts by student-athletes. Specifically, the heavily publicized determination by NU football players to be characterized as employees and organize as a union, followed by the highly controversial success of the UM football players' protests leading to the University president's resignation, provide blueprints for the future of mobilized efforts across college campuses.

\section{Northwestern University and the NLRB: 2013-2014}

In 2013, former NU quarterback Kain Colter and at least a dozen others wrote "APU" in large white letters on his wrist tape standing for "All Players United," a reform campaign led by the National Collegiate Players Association (NCPA), an advocacy group supported by the U.S. Steelworkers union. ${ }^{120}$ Utilizing the hashtag \#APU on Twitter, the NCPA drew attention to various concerns and collective goals among football players across the nation, including pressing for better concussion

\footnotetext{
${ }^{119}$ See Victor Mather, William Paterson Forfeits Game after Coach's Departure, N.Y. TimEs (Nov. 25, 2015), http://www.nytimes.com/2015/11/26/sports/ncaabasketball/william-paterson-forfeitsgame-after-coachs-departure.html; see also Jerry Carino, William Paterson Players Walk off Court in Protest, APP.com (Nov. 25, 2015), http://www.app.com/story/sports/college/2015/11/24/ william-paterson-players-walk-off-court-protest/76353268/.

120 See Patrick Hruby, Can College Athletes Unionize?, PatrickHruby.net (Jan. 28, 2014), http://www.patrickhruby.net/2014/01/can-college-athletes-unionize.html (offering that an online petition that read, "I'm joining players and fans from campuses across the nation to stand against unjust NCAA rules that leave college athletes without basic protections. Players should not be forced to forfeit their rights and endure unnecessary physical, academic, and financial risks as a condition of participating in NCAA sports.").
} 
and other medical protections, and for scholarships to cover the actual, full cost of attendance at a college or university. ${ }^{121}$

The NCAA's response was firm, stating that "student-athletes are not employees within any definition of the National Labor Relations Act . .." and "This unionbacked attempt to turn student-athletes into employees undermines the purpose of college: an education ...."122 Further, the NCAA reiterated that, "Student-athletes are not employees, and their participation in college sports is voluntary. We stand for all student-athletes, not just those the unions want to professionalize." 123 However, the NCAA also maintained that it still "supports open and civil debate regarding all aspects of college athletics." 124

In a similar response, Jim Phillips, NU's Vice-President of Athletics and Recreation, stated "Northwestern believes that our student-athletes are not employees and collective bargaining is therefore not the appropriate method to address these concerns..." Phillips continued, "However, we agree that the health and academic issues being raised by our student-athletes and others are important ones that deserve further consideration." 125

Despite the pushback from both the NCAA and Northwestern, Colter and the NCPA persevered and filed a petition to form a union at the NLRB regional office in Chicago (Region 13) on behalf of NU football players, claiming they are entitled to unionize and be considered employees. ${ }^{126}$ This petition led to a federal NLRB hearing in Chicago in February, 2014 to determine whether the players' unionization attempt could proceed. ${ }^{127}$

\footnotetext{
${ }^{121}$ See Tom Farrey, Kain Colter Starts Union Movement, ESPN.com (Jan. 28, 2014), http://espn. go.com/espn/otl/story/_id/10363430/outside-lines-northwestern-wildcats-football-players-tryingjoin-labor-unionFarrey. Colter stated, “The action we're taking isn't because of any mistreatment by Northwestern...We love Northwestern...We're interested in trying to help all players...Right now the NCAA is like a dictatorship. No one represents us in negotiations. The only way things are going to change is if players have a union."
}

${ }^{122}$ Id. Statement made on behalf of the NCAA by its Chief Legal Officer, Donald Remy; see also National Labor Relations Act (NLRA), 29 U.S.C. $§ 151$ et seq. (2015). This act is sometimes referred to as the Wagner Act after New York Senator Robert F. Wagner.

${ }^{123} \mathrm{Id}$.

${ }^{124}$ See Sara Ganim, Several Football Players Take Part in Protest for NCAA Reforms, CNN. COM (Sept. 23, 2013), http://www.cnn.com/2013/09/21/sport/college-football-protest/ (offering that various issues plague the NCAA including controversies over player suspensions, academic scandals, and medical concerns).

${ }^{125}$ Farrey, supra note 121.

${ }^{126} I d$. (referencing the 1953 Univ. of Denver v. Nemeth case discussed supra note 30, in which Ernest Nemeth was indeed characterized as an employee as a student-athlete but under much different circumstances which would clearly be in violation of NCAA rules today).

127 See Teddy Greenstein, NU's Colter States Case for Union at NLRB Hearing, CHI. TRIB. (Feb. 18, 2014), http://articles.chicagotribune.com/2014-02-18/sports/chi-kain-colter-ncaa-nlrbunion-hearing-20140218_1_nu-football-players-national-labor-nlrb; see also Alejandra Cancino \& Teddy Greenstein, Northwestern Coach Fitzgerald Expected to Testify at Union Hearing Friday, CHI. TRIB. (Feb. 20, 2014), http://articles.chicagotribune.com/2014-02-20/ business/chi-northwestern-football-player-union-case-20140220_1_nlrb-northwestern-university-football-players-pat-fitzgerald; see also Alejandra Cancino, NU gets Lift at Final Day of Labor Hearing, CHI. TRIB. (Feb. 26, 2014), http://articles.chicagotribune.com/2014-02-26/site/ ct-northwestern-football-nlrb-0226-biz-20140226_1_football-players-pat-fitzgerald-football-coach. 


\section{The Chicago District Ruling (Region 13)}

In March, 2014 the Chicago district of the NLRB (Region 13) ruled that NU's scholarship football players were in fact employees of NU under the National Labor Relations Act (NLRA) and could unionize and bargain collectively. ${ }^{128}$ The Region 13 decision, made by Regional Director Peter Sung Ohr, concluded that Northwestern football players "receive the substantial economic benefit" of scholarship money in exchange for performing football-related services under what amounts to a contract for hire. ${ }^{129}$

Ohr found that the NU football players' activities were primarily economic. ${ }^{130}$ Of particular interest to Ohr was the amount of control exerted over the studentathletes' lives. ${ }^{131}$ The ruling cited multiple factors and concluded that the scholarship football players (as opposed to the non-scholarship "walk-on" athletes) at Northwestern are employees in that that they perform services for the benefit of their employer and receive compensation (in the form of a scholarship) in exchange, and that scholarship players are "subject to the employer's control in the performance of their duties as football players." 132

Ohr also differentiated NU's football players from graduate teaching assistants at Brown University ${ }^{133}$ (in which the NLRB ruled in favor of the university), noting that at Northwestern "the players' football-related duties are unrelated to their academic studies as compared to the graduate assistants whose teaching and research duties were inextricably tied to their graduate degree requirements." 134 Ohr stated, "The players spend 50 to 60 hours per week on their football duties during a onemonth training camp prior to the start of the academic year and an additional 40 to 50 hours per week on those duties during the three or four month football season. Not only is this more hours than many undisputed full-time employees work at their jobs, it is also many more hours than the players spend on their studies." 135

Ohr's ruling applied only to private colleges, as public institutions are governed by state labor laws which deny student-athletes the right to petition at the state level to unionize. ${ }^{136}$ The Region 13 decision became an overnight sensation, resulting in over 13,000 Internet plugs. The states of Michigan and Ohio implemented laws

\footnotetext{
${ }_{128}$ Northwestern Univ., Case 13-RC-121359 (N.L.R.B. Region 13, Mar. 16, 2014).

${ }^{129} \mathrm{Id}$. at $13-14$.

${ }^{130} I d$. at $18-19$.

${ }^{131} I d$. at 14-16 (Ohr states, "In the instant case, the record establishes that the players who receive scholarships are under strict and exacting control by their Employer throughout the entire year.").

${ }^{132} I d$. at 15.

${ }^{133}$ Brown Univ., 342 N.L.R.B. 483 (2004).

${ }^{134} I d$. at 18 .

${ }^{135} \mathrm{Id}$.

136 See Michael Sanserino, College Athletes Union Raises Tax, Discrimination Questions, Pittsburgh Post-Gazette (Apr. 6, 2014), http://www.post-gazette.com/business/ employment/2014/04/06/College-athletes-union-raises-tax-discrimination-questions/ stories/201404030298.
} 
barring student-athletes from the right to unionize at all. ${ }^{137}$ Although an historic conquest for NU football players at the Regional level, such attempt was shortlived and, in retrospect, merely a Pyrrhic victory. On July 3, 2014, NU appealed the decision to the federal NLRB in Washington, D.C. (NLRB). ${ }^{138}$

\section{The Federal NLRB Decision: 2015}

On appeal, in August 2015 the NLRB unanimously declined to rule on the Northwestern case in a somewhat ambiguous decision, stating that it was not judging the merits of the student-athletes' argument, but noting that its board could later readdress the issue. ${ }^{139}$ The NLRB's decision, however, purposefully dismissed Ohr's Region 13 decision. ${ }^{140}$

In declining to assert jurisdiction on this matter, the NLRB noted that the issue of college football players' broad efforts to unionize affects both public and private institutions. ${ }^{141}$ Because the NLRB has no authority over public institutions, any ruling on this issue would destabilize the competitive balance between public and private universities. The NLRB stated,

"Our decision is primarily premised on a finding that, because of the nature of sports leagues (namely the control exercised by the leagues over the individual teams) and the composition and structure of [Football Bowl Subdivision] football (in which the overwhelming majority of competitors are public colleges and universities over which the board cannot assert jurisdiction), it would not promote stability in labor relations to assert jurisdiction in this case." ${ }^{142}$

The NLRB further stipulated three times within its decision that, "it would not effectuate the policies of the Act to assert jurisdiction . . .."143 The fact that the

\footnotetext{
${ }^{137}$ See Adam Epstein \& Paul Anderson, The Relationship between a Collegiate Student-Athlete and the University: An Historical and Legal Perspective, forthcoming, 26 MARQ. SPORTS L. REv. 1, 10 (2016) (referencing Student's not employee's based upon athletic participation, OHIO REv. CoDE $\$ 3345.56$ (2015); Definitions; rights of public employees, MicH. CoMP. Laws 423.201 (1(e (iii))) (2015)).

${ }^{138}$ See Alan K. Cubbage, Northwestern Asks National Labor Relations Board to Overturn Regional Director's Ruling on Football Players Unionization, NorTHWESTERn.Edu (July 3, 2014), http:// www.northwestern.edu/newscenter/stories/2014/07/northwestern-asks-nlrb-to-overturn-regionaldirector-ruling-on-football-players-unionization.html.

139 Northwestern Univ., 362 N.L.R.B. No. 167 (Aug. 17, 2015); see also Ben Strauss, N.L.R.B. Rejects Northwestern Football Players' Union Bid, N.Y. TIMES (Aug. 17, 2015), http://www. nytimes.com/2015/08/18/sports/ncaafootball/nlrb-says-northwestern-football-players-cannotunionize.html?_r=0.

${ }^{140}$ Northwestern Univ. at 7.

${ }^{141}$ Id.; see also Sheldon D. Pollack \& Daniel V. Johns, Northwestern Football Players Throw a "Hail Mary" But the National Labor Relations Board Punts: Struggling to Apply Federal Labor Law in the Academy, 15 VA. SPORTS \& ENT. L.J. 77, 81 (2015) (offering that given the NLRB's refusal to intervene, the authors provide other options as alternatives to collective bargaining).

${ }^{142} I d$.

${ }^{143} I d$. at 1,3 , and 6 (referencing the NLRA $\S 2(3)$ ).
} 
NLRB avoided making a definitive ruling on this particular issue was disappointing to the NU football players, but not ultimately surprising. For decades, the NLRB's analyses and decisions pertaining to student employees, graduate student assistants, teaching assistants and student unions has been largely chaotic and inconsistent, resulting in erratic and unpredictable decisions over the years. ${ }^{144}$

${ }^{144}$ See, e.g., Yuki Noguchi, Are Grad Students Employees? Labor Board to Again Weigh In, NPR. ORG (Apr. 7, 2016), http://www.npr.org/sections/ed/2016/04/07/473381993/are-grad-studentsemployees-labor-board-to-again-weigh-in?utm_campaign=storyshare\&utm_source=twitter. com\&utm_medium=social (offering that the NLRB has "flip-flopped" in its policy at that though it has held that students were not employees for decades. In 2000 it changed its position and ruled in favor of students. Then, four years later, the NLRB reversed itself and is now considering changing its position again); see also Adelphi Univ., 195 N.L.R.B. 639 (1972) (holding that graduate student assistants are primarily students and should be separated from typical faculty members; services of a graduate assistant are more academic than economic); Leland Stanford Junior Univ., 214 N.L.R.B. 621 (1974) (holding that graduate assistants are not university employees; relationship between graduate assistant and university "is not grounded on the performance of a given task where both the task and the time of its performance is designated and controlled by an employer. Rather it is a situation of students within certain academic guidelines having chosen particular projects on which to spend the time necessary" to complete project); S.F. Art Inst., 226 N.L.R.B. 1251 (1976) (holding that student janitors, who were either on tuition scholarship, or paid monthly or hourly, were not considered employees of the university when considering that position as janitors was incidental to education interests, student janitors only worked part time ( 20 hours per week) and did not retain the same position after graduation, and did not "share a substantial community of interest with regular nonstudent full-time and part-time employees."); Bos. Med. Ctr. v. House Officers' Ass'n/Comm. of Interns and Residents, 330 N.L.R.B. 152 (1999) (deciding that interns, residents, and fellows employed by medical center while students learning particular medical expertise were also considered employees for purposes of a collective bargaining unit); N.Y. Univ. v. Int'l Union, United Auto., Aerospace and Agric. Implement Workers of Am., 332 N.L.R.B. 1205 (2000) (NYU graduate assistants considered employees under NLRA such that they could organize and bargain with employer even though they are enrolled as students; case was overruled in 2004); Brown Univ. v. Int'l Union, United Auto., Aerospace and Agric. Implement Workers of Am., 342 N.L.R.B. 483 (2004) (holding that graduate assistants are not employees for statutory purposes; students are admitted to university, not hired by university, and supervised teaching/research is integral component of students' academic development); Benjamin J. Kozik v. Hamilton Coll., Complaint, No. 6:12-cv-01870-LEK-TWD (N.D.N.Y. 2012) (alleging that interns working in athletic department were not paid overtime wages for weekly hours over 40 per week or daily for days long than 10 hours, and that college failed to pay intern minimum wages as required by law, that college failed to keep and preserve accurate records of interns and employees, and that college failed to compensate interns for "spread-of-hours" work as required by law); DTR Indus., Inc. v. N.L.R.B., 297 F. App'x. 487 (6th Cir. 2008) (deciding that employer's Chief Human Resources Officer's statements that employees would be fired if they unionized, although objective predictions and protected speech, were in violation of the NLRA because of their coercive nature; similarly, threatening to punish individual employee for union activity and suggesting he was under surveillance violated NLRA); N.L.R.B. v. Bell Aerospace Co. of Textron, Inc., 416 U.S. 267 (1974) (holding that Congress intended to exclude from protections of NLRA all employees properly classified as "managerial," as opposed to those in positions susceptible to labor relations conflicts of interest; NLRB is not required to proceed by rulemaking rather than by adjudication when determining whether particular buyers are "managerial employees."); N.L.R.B. v. Town \& Country Elec., Inc., 516 U.S. 85 (1995) (offering that a worker may be an 
Although this decision ultimately resulted in a loss to NU football players' attempt to unionize and bargain collectively, the front page media blitz that the NU cases garnered over a two year period further propelled the national debate over whether student-athletes should be considered employees of their institutions, and helped cultivate the media's growing obsession with student-athlete mobilization efforts. ${ }^{145}$ Just three months after the popularized NLRB decision, immense news attention shifted from Evanston, Illinois to Columbia, the county seat of Boone County, Missouri where a band of football players launched an overnight social media phenomenon to successfully oust the president of UM.

\section{The 2015 University of Missouri Mobilization}

In November 2015, more than 30 African American football players at the UM mobilized together, refusing to practice or play against BYU unless University President Timothy Wolfe resigned. ${ }^{146}$ Concurrently, Missouri graduate student Jonathan Butler commenced a hunger strike in opposition of Wolfe, leading to numerous UM football players sending supportive tweets under the hashtag, \#ConcernedStudent1950. ${ }^{147}$

\footnotetext{
"employee" of a company under terms of NLRA even if worker simultaneously is paid by union to help union organize the company); NYU \& GSOC/UAW, 356 N.L.R.B. No. 7 (2010) (deciding that the petition be re-instated for full hearing on issue whether graduate students at NYU were "employed" to provide teaching and research services; students argued for an over-ruling of the Brown case given its policy considerations extrinsic to labor law, and the board decided that factual representations and evidence of both parties should be heard in full at a hearing; University argued that the Board should not review the Regional Director's order dismissing petition because of the Board's own Rules and Regulations). Special thanks to Paul Anderson for his overall research related to this footnote.

145 See LaKe The Posts, The Current Team Leadership Void (Mar. 31, 2014), http://www.laketheposts.com/2014/03/31/the-current-team-leadership-void/ (noting that Northwestern football players continue to get front page treatment from coast to coast).

${ }^{146}$ See, e.g., Marc Tracy \& Ashley Southall, Black Football Players Lend Heft to Protests at Missouri, N.Y. Times (Nov. 8, 2015), http://www.nytimes.com/2015/11/09/us/missouri-football-playersboycott-in-protest-of-university-president.html. Notice the irony that the game was against BYU, the same institution at the heart of the Black 14 protests involving the Wyoming and San Jose State discussed supra, notes 87-91. Also, it should be noted that Ferguson, Missouri, was the place where Michael Brown, an unarmed black teenager, was fatally shot during a scuffle with a police officer in August, 2014, sparking the national "Black Lives Matter" movement. See Shannon Luibrand, How a Death in Ferguson Sparked a Movement in America, CBS News (Aug. 7, 2015), http:// www.cbsnews.com/news/how-the-black-lives-matter-movement-changed-america-one-year-later/.

147 See Cassandra Vinograd, \#ConcernedStudent1950 Protest at University of Missouri Picks Up Steam, NBC News (Nov. 9, 2015), http://www.nbcnews.com/news/us-news/concernedstudent1950-protest-university-missouri-picks-steam-n459671. 1950 was the year that the university began accepting black students. See Matt Pearce \& Lauren Raab, University of Missouri Football Team and Coach Join Protest to Oust University Leader, LATimes.COM (Nov. 8, 2015), http:// www.latimes.com/nation/la-na-missouri-protest-20151108-story.html.
} 
Mounting pressure to have Wolfe removed or purposefully resign from UM culminated when head football coach Gary Pinkel and his athletics department staff joined the public efforts. ${ }^{148}$ After a meeting with his team, Pinkel publicly declared his support for the demonstration against Wolfe, posting a team photo on Twitter and tweeting, "The Mizzou family stands as one. We are united. We are behind our players." "149 Two days later, Wolfe resigned, and Missouri named Michael Middleton, an African American, as Interim President. ${ }^{150}$ The UM-BYU game commenced as scheduled on Saturday, November 15, 2015, ${ }^{151}$ but Coach Pinkel cancelled practices and team activities scheduled for the next day. ${ }^{152}$

In response to the activist efforts launched by UM student-athletes, in December, 2015 a bill was proposed in the Missouri legislature that would revoke the scholarships of student-athletes who participate in strikes in the future. ${ }^{153}$ Specifically, the text of House Bill No. 1743 read,

1. Notwithstanding any other provision of law, any college athlete who calls, incites, supports, or participates in any strike or concerted refusal to play a scheduled game shall have his or her scholarship revoked.

2. Any member of a coaching staff who encourages or enables a college athlete to engage in behavior prohibited under subsection 1 of this section shall be fined by his or her institution of employment. ${ }^{154}$

On December 16, 2015, the bill was withdrawn. ${ }^{155}$

${ }^{148} I d$.

${ }^{149}$ See ChipPatterson, Missouri Coach GaryPinkel,ADStandin SupportofPlayersonStrike, CBS SPORTS. COM (Nov. 8, 2015), http://www.cbssports.com/collegefootball/eye-on-college-football/25367110/ missouri-coach-gary-pinkel-tweets-team-photo-supports-striking-players.

${ }^{150}$ See John Eligon \& Richard Perez-Pena, University of Missouri Protests Spur a Day of Change, N.Y. Times (Nov. 9, 2015), http://www.nytimes.com/2015/11/10/us/university-of-missouri-systempresident-resigns.html (offering that in addition to the president Timothy M. Wolfe, the chancellor R. Bowen Loftin would step down as well). See also University of Missouri System, UM Board of Curators Appoints Michael Middleton as Interim President of the UM System (Nov. 12, 2015), https://www.umsystem.edu/stories/curators_announce_interim_president (naming Middleton as Interim President).

151 See ESPN, Missouri Caps Tumultuous Week with 20-16 Victory over BYU, ESPN.cOM (Nov. 15, 2015), http://espn.go.com/college-football/recap?gameId=400785063.

${ }^{152}$ See Tracy \& Southall, supra note 146 (noting that it was announced in a joint statement with the athletics director).

${ }^{153}$ See H. 1743, $98^{\text {th }}$ Leg., $2^{\text {nd }}$ Reg. Sess. (Mo. 2015).

${ }^{154} \mathrm{Id}$.

${ }^{155} \mathrm{Id}$. 
The mobilized endeavor at the UM comprising students, student-athletes, and coaching staff documents an unparalleled social media extravaganza leading to the successful prompting of change on a college campus. ${ }^{156}$ Reports indicate that within an hour of Wolfe's resignation, his name had been tweeted more than 20,000 times. ${ }^{157}$

With the advent of social media's web-savvy, app-friendly Generation Z (also referred to as "iGen"), college campuses provide a unique platform for promoting attention on a global scale. ${ }^{158}$ Amid the publicity surrounding the Northwestern and Missouri football players' consummate mobilized efforts, the NCAA's reaction has been robust, perhaps in preparation for the continuing evolution of the intercollegiate landscape encompassing social media and student-athlete activist efforts.

\section{The NCAA and the Evolving Intercollegiate Landscape}

Prior to the notoriety of the NLRB and Missouri mobilization efforts, a class action antitrust lawsuit, led by former UCLA basketball player Ed O'Bannon, over the commercial exploitation of college athletes was filed against the NCAA. ${ }^{159}$ In a 2014 decision, Federal District Judge Claudia Wilken ruled in favor of O'Bannon and the remaining plaintiffs, finding that the NCAA was in violation of antitrust laws, and held that players should receive compensation to bridge the full "cost of

156 It should be noted that in April, 2016, graduate students at the University of Missouri voted
in favor of unionization. See Courtney Kueppers, Graduate Students at U. of Missouri Vote in
Favor of Unionization, CHRON. HIGHER EDUC. (Apr. 20, 2016), http://chronicle.com/blogs/ticker/
graduate-students-at-u-of-missouri-vote-in-favor-of-unionization/110563. On the UM campus
the next month, the Missouri softball team mobilized against their own athletics department and
specifically their athletics director Mack Rhodes for a curious internal investigation that cast a
"black cloud" over the program related to supposed internal and external complaints over the
program. In fact, the players finished out their 2016 "in protest" of what they felt was an unjust
investigation against their softball program, their coaching staff and Head Coach Erhen Earleywine.
As part of their official statement signed and released just before a game in early May, the women
wrote, "The administration was completely incompetent in handing the fall football scandal and
they are doing a worse job at this." See Tod Palmer, Mizzou Softball Team Upset with Investigation
into Coach, Plays Game 'In Protest', KANSAs CiTy STAR (May 7, 2016), http://www.kansascity.
com/sports/college/sec/university-of-missouri/article76296187.html.

${ }^{157}$ See Julia Glum, After Missouri's Tim Wolfe Resigns, Twitter Reacts: Students and Protestors Rejoice, Critics Respond on Social Media, InT'L Bus. Times (Nov. 9, 2015, 12:30PM), http://www.ibtimes. com/after-missouris-tim-wolfe-resigns-twitter-reacts-students-protesters-rejoice-critics-2175727. ${ }^{158}$ See Brian Mastroianni, How Generation Z is Changing the Tech World, CBS News (Mar. 10, 2016, 6:00AM), http://www.cbsnews.com/news/social-media-fuels-a-change-in-generationswith-the-rise-of-gen-z/ (discussing Generation $\mathrm{Z}$ and social media).

${ }^{159}$ See, e.g., Karen Crouse, When an Olympian Goes to College, Riches Stay out of Reach, N.Y. Times (Apr. 16, 2016), http://mobile.nytimes.com/2016/04/17/sports/olympics/katie-ledeckyolympian-goes-to-college-riches-stay-out-of-reach.html. 
attendance" at college. ${ }^{160}$ On appeal, the Ninth Circuit Court of Appeals affirmed Judge Wilken's decision in part, but rejected that part of her ruling allowing schools to offer money in exchange for the use of players' likeness. ${ }^{161}$

The O'Bannon case is just one of numerous legal challenges filed against the NCAA by former student-athletes from a variety of institutions in recent years, though many have been settled or dismissed. ${ }^{162}$ Although challenging status quo is not an innovative concept for student-athletes in the modern era, and certainly does not always play into their favor, collective college athlete action has incited important changes to the NCAA regulations. ${ }^{163}$

${ }^{160}$ O’Bannon v. NCAA, 7 F. Supp. 3d 955 (N.D. Cal. 2014) (ruling that the NCAA violated antitrust laws and could not stop member schools from depositing revenues from the use of student-athlete's names and likenesses into a trust account for the student-athlete at an amount up to $\$ 5,000$ per year). For further discussion on the O'Bannon case, see Epstein \& Anderson, supra note 137.

${ }^{161}$ O’Bannon v. NCAA, 802 F.3d 1049 (9th Cir. 2015) (vacating the district court's judgment and ordering a permanent injunction insofar as requiring the NCAA to allow its member schools to pay student-athletes up to $\$ 5,000$ per year in deferred compensation).

162 See, e.g., Berger v. NCAA, 2016 U.S. Dist. LEXIS 18194, 26 Wage \& Hour Cas. 2d (BNA) 38 (S.D. Ind. Feb. 16, 2016); (dismissal of complaint alleging that the NCAA and its member institutions violate the Fair Labor Standards Act, 29 U.S.C. $\$ \S 201$ et seq. ("FLSA") with regard to the wage-and-hour provisions of the FLSA to be paid at least minimum wage for the work they perform as student-athletes); see also Keller v. Elec. Arts, Inc., 724 F.3d 1268 (9th Cir. 2013) (alleging improper use of image and likeness of student-athletes in EA Sports' series of NCAA Football videogames); Hart v. Elec. Arts, Inc., 808 F. Supp. 2d 757, 2011 U.S. Dist. LEXIS 101254, 101 U.S.P.Q.2d (BNA) 1561 (D.N.J. 2011), 717 F.3d 141 (3d Cir. 2013) (holding that the First Amendment does not trump the student-athletes' right of publicity in the context of video game use of their likenesses).

${ }^{163}$ See, e.g., Adam Epstein, Surveying Colorado Sports Law, 2 Rocky Mountain L. J. 2, 8 (2014) (discussing the plight of NCAA multi-sport student-athlete Jeremy Bloom who unsuccessfully challenged the NCAA's no-endorsement rule which prevented him from remaining eligible in football if he accepted sponsorship with a clothing manufacturer for his Olympic sport of mogul skiing in Bloom v. Nat'1 Collegiate Athletic Ass'n, 93 P.3d 621 (Colo. App. 2004)); see also ADAM EPSTEIN, SPORTS LAW (2013) (discussing the case of Ohio native Andy Oliver, a former NCAA baseball player from Oklahoma State University who successfully challenged the NCAA's no-agent rule, leading to an out-of-court settlement with the NCAA after the trial court decision in Oliver v. Nat'1 Collegiate Athletic Ass'n, 155 Ohio Misc.2d 17, 2009-Ohio-6587, 920 N.E.2d 203). See Andrew Gottesman, NCAA Gives NU's Autry His First Big Break in Movies, CHI. TrIB. (Apr. 6, 1996) (reporting that the NCAA granted a waiver to Autry so that he could fly to Italy for a small part in the movie "The Eighteenth Angel." At that time, the NCAA disallowed student-athletes from working during school months, or from gaining advantages unavailable to other students. In fact, according to the article, NCAA rules at that time actually allowed student-athletes to appear in made-for-TV movies but not commercial films.). 


\section{Expedited Modification of the NCAA System and Regulations}

As a direct result of the O'Bannon case and other outspoken current-and former student-athletes, the NCAA was essentially forced to make select changes in order to secure some level of respect in the court of public opinion. For example, contemporaneous to NU football players challenging the amateurism model of the NCAA, University of Connecticut basketball player Shabazz Napier's told reporters in April 2014 that he often went to bed "starving," prompting the NCAA to immediately pass legislation allowing for expanded year-round meals for athletes. ${ }^{164}$ In a separate example, the NCAA recently granted more autonomy to Power 5 conferences [encompassing the Atlantic Coast Conference (ACC), Big 10, Big 12, Pac-12, and the Southeastern Conference (SEC)]. ${ }^{165}$ Under this new model, NCAA Division I schools can offer scholarships covering the full cost of attending the university, coaches can no longer strip a student-athlete's scholarship funds for purely athletic reasons, and student athletes can borrow against future earnings when getting loss-of-value insurance. ${ }^{166}$

At the 2016 NCAA Convention, the Power 5 conferences voted to loosen certain rules restricting how Division I baseball and men's basketball players can interact with professional sports teams, allowing basketball players to enter the NBA draft multiple times and permitting baseball players to hire agents. ${ }^{167}$ Further,

164 See Alicia Jessop, The NCAA Approves Unlimited Meals for Division I Athletes after Shabazz. Napier Complains of Going Hungry: The Lesson for Other College Athletes, FoRBEs.COM (Apr. 15, 2014), http://www.forbes.com/sites/aliciajessop/2014/04/15/the-ncaa-approves-unlimited-meals-fordivision-i-athletes-after-shabazz-napier-complains-of-going-hungry-the-lesson-for-other-collegeathletes/\#50b45c347c91; see also Sara Ganim, UConn Guard on Unions: I Go to Bed 'Starving', CNN (Apr. 8, 2014, 1:26PM ET), http://www.cnn.com/2014/04/07/us/ncaa-basketball-finalsshabazz-napier-hungry/. Also in 2014, Indiana University (IU) became the first big-time university in the country to formally establish a Bill of Rights for student-athletes. The ten-point document addresses concerns by student-athletes involving amateurism and college sports, and among the benefits that IU guarantees includes guaranteed multiyear scholarships to full-scholarship athletes, financial support to former athletes who return to IU to finish their degrees, increase its healthcare commitments to student-athletes, and providing all athletes with personal iPads. No doubt, the impact of student-athlete outcry at the national scale influenced IU to establish such a program in a timely manner. See Zach Osterman, IU Implements 'Bill of Rights' for Athletes, Indy STAR (June 27, 2014), http://www.indystar.com/story/sports/college/indiana/2014/06/27/iu-implements-billrights-athletes/11494425/. The ten complete IU Student-Athlete Bill of Rights may be accessed at http://sidearm.sites.s3.amazonaws.com/iuhoosiers.com/documents/2015/3/20/Bill-of-Rights.pdf.

${ }^{165}$ Epstein \& Anderson, supra note 137. For further discussion of the Power 5 conferences, see Jon Solomon, Power Five Autonomy Has Created a Small Subset of NCAA Dysfunction, CBS SPORTS (Apr. 24, 2016), http://www.cbssports.com/collegefootball/writer/jon-solomon/25565244/ power-five-autonomy-has-created-a-small-subset-of-ncaa-dysfunction.

166 Id.; see also Steve Berkowitz, NCAA Increases Value of Scholarships in Historic Vote, USA TodAY (Jan. 17, 2015), http://www.usatoday.com/story/sports/college/2015/01/17/ ncaa-convention-cost-of-attendance-student-athletes-scholarships/21921073/.

${ }^{167}$ See Jake New, Flirting with Professional Sports, InsideHighERED.com (Jan. 20, 2016), https:// www.insidehighered.com/news/2016/01/20/new-ncaa-rules-allow-athletes-interact-more-freelyprofessional-sports (discussing the NCAA now allowing student-athletes to enter the draft multiple times and pushes back the date by which an athlete must remove his name from the National Basketball Association draft in order to remain eligible to play on a college team). 
new NCAA rules allow high school baseball players to hire agents without losing their NCAA eligibility whereas previously, if a high school player hired an agent, the NCAA considered him to no longer be an amateur athlete and therefore ineligible. ${ }^{168}$ Finally, effective May, 2016, the NCAA passed a rule allowing athletic departments the opportunity to provide summer scholarship funds to full and partial student-athlete scholarship recipients. ${ }^{169}$ Indeed, we believe it is reasonable to assume that many of these immediate changes by the NCAA may be directly related to the use of social media to manage the court of public opinion. ${ }^{170}$

\section{Claims of Economic Injustice and the Future}

One area within its regulations that the NCAA has thus far refused to change, no matter the pressure exerted, is its fundamental principle of amateurism. ${ }^{171}$ This principle ensures that student-athletes who are, or have been, paid to play are essentially permanently ineligible to compete in varsity athletic competition. ${ }^{172}$ Although the issue of paying student-athletes received national fame during the 2013 college football season with former Texas A\&M quarterback Johnny Manziel, perceptions of economic injustice in every form within the college athletic arena has garnered heavy public scrutiny. ${ }^{173}$

${ }^{168} I d$.

${ }^{169}$ See Brad Wolverton, NCAA Eases Scholarship Restrictions, Raising Concerns Over Competitive Equity, Chron. Higher Educ. (May 17, 2016), http://chronicle.com/article/NCAA-EasesScholarship/236495/\#st_refDomain=t.co\&st_refQuery=/aFT1KqVNxQ.

170 See, e.g., Gary Parrish, Those Clips Didn't Get Mike Rice Fired as Much as the Reaction Did, CBS SPORTS (Apr. 3, 2013), http://www.cbssports.com/collegebasketball/eye-on-collegebasketball/22000629/that-video-didnt-get-mike-rice-as-much-as-the-reaction-did (offering that very important decisions are often made in reaction to commentary made on and the related pressure due to instant access social media outlets such as Twitter).

171 See, e.g., NCAA Manual art. 2.9, The Principle of Amateurism. ("Student-athletes shall be amateurs in an intercollegiate sport, and their participation should be motivated primarily by education and by the physical, mental and social benefits to be derived. Student participation in intercollegiate athletics is an avocation, and student-athletes should be protected from exploitation by professional and commercial enterprises."; see generally Adam Epstein \& Paul Anderson, Utilization of the NCAA Manual as a Teaching Tool, 26 J. Legal StUd. Educ. 109 (2009) (highlighting that the word "amateurism" is mentioned almost 40 times in the 2012-13 NCAA Manual); T. Matthew Lockhart, Oliver v. NCAA: Throwing a Contractual Curveball at the NCAA's "Veil of Amateurism", 35 U. DAYTON L. REv.., 175, 186 (2010) (noting the deference that courts have given to the manner in which the NCAA defines amateurism).

172 Josephine (Jo) R. Potuto, William H. Lyons \& Kevin N. Rask, What's in a Name? The Collegiate Mark, the Collegiate Model, and the Treatment of Student-Athletes, 92 OR. L. REv. 879, 882 (2014).

173 See Kisska-Schulze \& Epstein, supra note 9 at 23 (discussing Johnny Manziel's notoriety during the 2013 football season). 
The disparity between the economic benefits received by student-athlete vis-àvis both their conference commissioners and coaches is embarrassingly monumental and continues to widen as coaching salaries skyrocket amidst the perpetual debate over whether student-athletes should be paid at all. ${ }^{174}$ For example, the University of Alabama (UA) head football coach Nick Saban is currently the highest coach in NCAA football history, earning more than $\$ 7$ million per year while even the UA strength coach made $\$ 600,000$ in $2015 .{ }^{175}$ Mark Emmert, President of the NCAA, is a multi-millionaire, as are now Power 5 conference commissioners and school athletic directors. ${ }^{176}$ Amid these staggering numbers, the NCAA rigidly maintains that student-athletes must view their participation in sports as an avocation only and as unpaid amateurs. ${ }^{177}$

When UCLA signed the largest apparel deal in the history of college athletics with Under Armour in spring 2016, quarterback Josh Rosen sarcastically tweeted, "We're still amateurs tho . . . gotta love non-profits. \#NCAA."178 The year before, two Stanford University football captains sat out a week of summer workouts and meetings in protest over the University's delay in providing the players scholarship money. ${ }^{179}$ The captains alleged that Stanford was late for the third summer in a row. ${ }^{180}$ Thus, though the NCAA maintains that student-athletes must not be paid, the NCAA cannot legislate that the student-athletes must not have an opinion on issues that matter to them, particularly financial ones.

174 See Steve Berkowitz, ACC reports $\$ 100$ million increase in total revenue in 2015 , USA Today (May 27, 2016), http://www.usatoday.com/story/sports/college/2016/05/27/ atlantic-coast-conference-total-revenue-increases-100-million/85035766/.

175 See Donald H. Yee, College Sports Exploits Unpaid Black Athletes. But They Could Force a Change, WASH. PosT (Jan. 8, 2016), https://www.washingtonpost.com/posteverything/ $\mathrm{wp} / 2016 / 01 / 08 /$ college-sports-exploits-unpaid-black-athletes-but-they-could-force-a-change/. See also Mbiyimoh Ghogomu, College Coaches are the Highest Paid Public Employees in 39 of the 50 U.S. States, Higher LeARNing (Jan. 5, 2015), http://thehigherlearning.com/2015/01/05/ college-coaches-are-the-highest-paid-public-employees-in-39-of-50-us-states/.

${ }^{176} I d$. (offering that Larry Scott, commissioner of the Pac-12 Conference, makes more than $\$ 3.5$ million a year).

177 NCAA Manual, 2.9, The Principle of Amateurism. ("Student-athletes shall be amateurs in an intercollegiate sport, and their participation should be motivated primarily by education and by the physical, mental and social benefits to be derived. Student participation in intercollegiate athletics is an avocation, and student-athletes should be protected from exploitation by professional and commercial enterprises."); see also Adam Epstein \& Paul Anderson, Utilization of the NCAA Manual as a Teaching Tool, 26 J. Legal StUd. EdUC. 109 (2009) (highlighting that the word "amateurism" is mentioned almost 40 times in the NCAA Manual).

178 See Steve DelVecchio, Rosen Takes Shot at NCAA over UCLA's Under Armour Deal, YARDBARKER (May 24, 2106), http://www.yardbarker.com/college_football/articles/josh_rosen_rips_ ncaa_after_ucla_signs_280_million_under_armour_deal/s1_127_20972038 (noting that the tweet was later taken down).

179 See Jon Solomon, Stanford Football Captains Protested Summer Workouts in 2015, CBS SPORTS (May 10, 2016), http://www.cbssports.com/collegefootball/writer/jon-solomon/25583091/ stanford-football-captains-protested-summer-workouts-in-2015.

${ }^{180} \mathrm{Id}$. 
In a similar example of where booming revenues in college sports may prompt allegations of economic injustice relevant to student-athletes, the College Football Playoff now generates $\$ 7$ billion from ESPN over the course of a 12-year contract. ${ }^{181}$ Basketball's March Madness tournament generates nearly \$11 billion from CBS Sports and Turner Broadcasting over a 14-year TV and Web contract agreement. ${ }^{182}$ Collegiate sports merchandising and licensing revenues exceed $\$ 4$ billion a year, and select conferences have their own television networks, to include the Pac-12 Network, the Big Ten Network, and the Longhorn Network. ${ }^{183}$

As pressure continues to mount over the debate about whether student-athletes should be characterized as employees of their institutions, there is budding momentum for student-athletes to turn to social media and the Internet to nationalize their protests, furthering boisterous movements which evolved from the earliest forms of race and inequality protests across college campuses. ${ }^{184}$ Whether that same courage and momentum which early student-athletes' efforts originally conjured will continue into the future ultimately depends on the passion of the players involved, and the media outlets which they use to bolster their voices which, in many cases, only last as long as their athletic scholarship of four years in general, unlike those who work in the public or private sector. ${ }^{185}$

Outside the U.S. judicial system forcing change to occur within intercollegiate sports programs, it is likely that near future NCAA bylaw or policy changes will be incremental at best. However, the newly-shaped spectrum of collective college athlete action successfully promoting change via use of Internet is certainly the next wave of the future. As the iGen class continues to penetrate college athletic programs, it is foreseeable that the use of social media to promote change will be the catalyst for NCAA reform moving forward. If recent history with the resignation of the UM president is any indication, the NCAA and member institutions must prepare for the influx of future student-athlete mobilization efforts using social media, and

\footnotetext{
${ }^{181}$ Yee, supra note 175.

${ }^{182} I d$.

${ }^{183} \mathrm{Id}$.
}

${ }^{184}$ See, e.g., Sarah Brown, Katherine Mangan \& Beth McMurtrie, At the End of a Watershed Year, Can Student Activists Sustain Momentum?, Chronicle.com (May 24, 2016), http:// chronicle.com/article/At-the-End-of-a-Watershed/236577 (discussing the UW Blackout activist group at the University of Wisconsin-Madison and Concerned Student 1950 student protests at the University of Missouri-Columbia in 2015-2016); see also Josh Logue, 9-Day Sit-In Ends, INSIDEHigheRED.COM (Apr. 25, 2016), https://www.insidehighered.com/news/2016/04/25/ clemson-students-end-lengthy-sit; see also Fernanda Zamudio-Suaréz, Duke Protesters Face Disciplinary Charges over Sit-In, CHRON. Higher EdUc. (Apr. 21, 2016), http://chronicle.com/ blogs/ticker/duke-protestors-face-disciplinary-charges-over-sit-in/110604.

${ }^{185}$ Brown, Mangan \& McMurtrie, supra (stating that graduation is a significant obstacle for campus activism); see also Andrew Surma, Mountain Madness: Student Activists Who Occupied Central Hall, Warriner Mall Return to Mount Pleasant, CM-Life (May 26, 2016), http://www.cm-life.com/ article/2016/05/mountain-madness-16 (stating, "In May 1970, student activists at Central Michigan University took a stand the City of Mount Pleasant hadn't seen before and has not seen since. With war raging on in Vietnam, Laos and Cambodia and the Ohio National Guard shooting dead four Kent State University student protesters, CMU students flooded the ROTC building - Central Hall (built in 1909 and demolished in 1974) — for five days of protest beginning May 4, 1970.”). 
ultimately decide whether the court of national public opinion will pressure the non-profit organization to ultimately mandate change within its Indianapolis-based headquarters and its coast-to-coast college athletic programs as well.

\section{Conclusion}

Following the 2015 resignation of University of Missouri President Tim Wolfe, the question of what student-athlete mobilization efforts may look like in the future prompts reasonable concern for the NCAA and its member institutions. Although history shows that not all mobilization efforts have proven to be as successful as the Missouri boycott, history proves that student-athletes have a powerful voice in promoting national debate and in many cases effectuating change. Specifically, this article demonstrates that throughout history student-athletes have assumed strong collective college athlete action, originating from the Willis Ward incident in Ann Arbor, to various Howard University protests, to protests over treatment of others based upon race. Individual actions over workers' compensation claims have almost universally failed; however, as have attempts to characterize student-athletes as employees in general such as the Northwestern University mobilization effort.

As a result of recent acts of activism by student-athletes, the NCAA has made significant changes to its bylaws while at the same time refusing to compromise its immemorial stance on amateurism. However, it is important to note that the Missouri football team's effort marks one of the most effective and passionate mobilization campaigns in recent college sports history, and may be the catalyst for reform within college athletic programs across the country. As the iGen class continues its social media savviness within the realm of college sports, both the NCAA and university athletic programs will be hard-pressed not to take into consideration the voices of a generation raised on Google, armed with the most powerful operating systems in history, and literally within the grasp of their \#hands. 